\title{
Russian Federation: 2004 Article IV Consultation-Staff Report; Staff Supplement; Public Information Notice on the Executive Board Discussion
}

Under Article IV of the IMF's Articles of Agreement, the IMF holds bilateral discussions with members, usually every year. In the context of the 2004 Article IV consultation with the Russian Federation, the following documents have been released and are included in this package:

- the staff report for the 2004 Article IV consultation, prepared by a staff team of the IMF, following discussions that ended on June 25, 2004, with the officials of the Russian Federation on economic developments and policies. Based on information available at the time of these discussions, the staff report was completed on August 5, 2004. The views expressed in the staff report are those of the staff team and do not necessarily reflect the views of the Executive Board of the IMF.

- $\quad$ staff supplement of August 30, 2004 updating information on recent developments.

- $\quad$ a Public Information Notice (PIN) summarizing the views of the Executive Board as expressed during its September 1, 2004 discussion of the staff report that concluded the Article IV consultation.

The documents listed below have been or will be separately released.

\section{Selected Issues Paper}

Statistical Appendix

The policy of publication of staff reports and other documents allows for the deletion of market-sensitive information.

To assist the IMF in evaluating the publication policy, reader comments are invited and may be sent by e-mail to publicationpolicy@imf.org.

$$
\begin{gathered}
\text { Copies of this report are available to the public from } \\
\text { International Monetary Fund • Publication Services } \\
70019^{\text {th }} \text { Street, N.W. • Washington, D.C. 20431 } \\
\text { Telephone: (202) 623-7430 • Telefax: (202) 623-7201 } \\
\text { E-mail: publications@imf.org Internet: http://www.imf.org }
\end{gathered}
$$

Price: $\$ 15.00$ a copy

\section{International Monetary Fund \\ Washington, D.C.}





\title{
INTERNATIONAL MONETARY FUND
}

\author{
RUSSIAN FEDERATION
}

\section{Staff Report for the 2004 Article IV Consultation}

\author{
Prepared by the Staff Representatives for the 2004 Consultation \\ with the Russian Federation
}

Approved by Michael Deppler and Carlos Muñiz

August 5, 2004

Article IV consultation discussions were held in Moscow during June 15-25, 2004.
The mission met Deputy Prime Minister Zhukov, Minister of Finance Kudrin,
Central Bank of Russia Governor Ignatiev, other senior officials, members of the
Duma, representatives of the business and academic communities, and the press.
The staff team comprised Mr. Thomsen (head), Mr. Lall (PDR), Mmes. Ohnsorge and
Oomes, Mr. Owen (all EUR), Messrs. Spilimbergo (FAD) and Teo (MFD), and was
assisted by Mr. Kwon (Moscow Office). Mr. Mozhin, Executive Director for Russia,
and Mr. Palei, Senior Advisor to the Executive Director, participated in the
discussions.
In the last consultation, concluded on May 2, 2003, Directors commended the
authorities for generally strong macroeconomic performance, but recommended a
stronger focus on reducing inflation, with fiscal policy geared toward containing
upward pressures on the real exchange rate. They urged the authorities to reinvigorate
structural reforms in order to boost long-term growth.
Pro-Kremlin parties won a two-thirds majority in Duma elections in December, and
President Putin was reelected in a landslide in March. Mr. Fradkov, the new
prime minister, has retained key economic ministers in the cabinet.
Russia has accepted the obligations of Article VIII, Sections 2, 3, and 4, but maintains
restrictions on current transactions that have not been approved by the Executive
Board (Appendix I).
A data transparency ROSC published in May 2004 concluded that Russia's statistical
database is adequate for surveillance, albeit with some shortcomings, and that
dissemination practices meet most of the SDDS requirements (Appendix III). Russia
has indicated to staff its intention to subscribe to the SDDS.




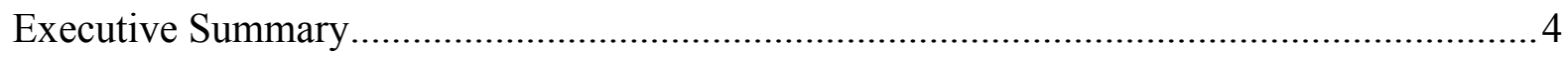

I. Economic Background .............................................................................................. 5

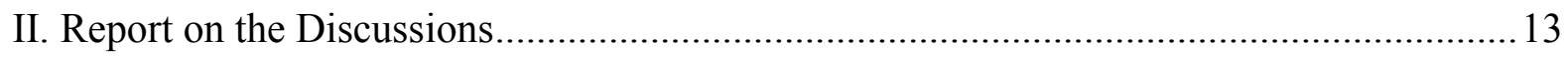

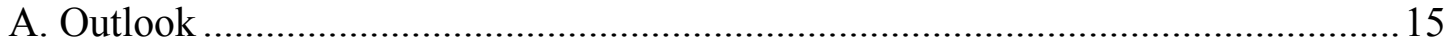

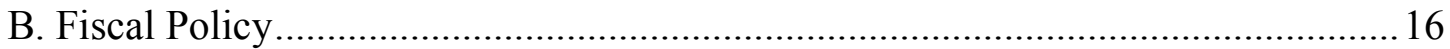

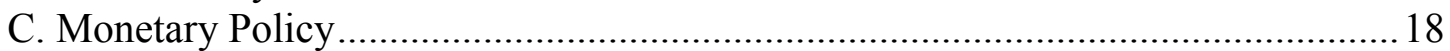

D. Financial Sector Vulnerabilities .................................................................. 21

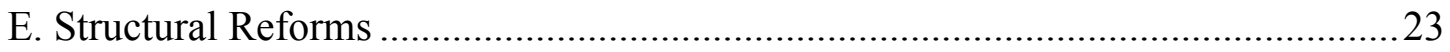

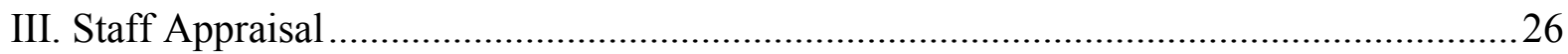

Boxes

1. The Russian Economy Since the 1998 Crisis.............................................................. 7

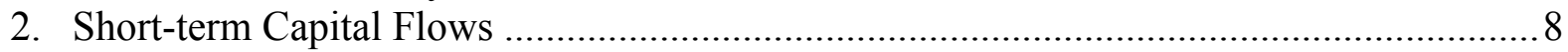

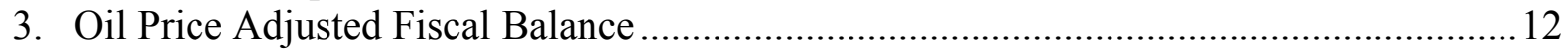

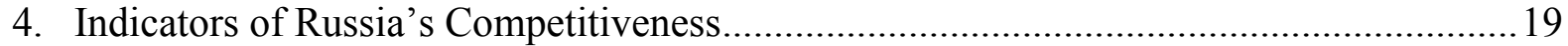

5. Medium-term Structural Fiscal Reforms .......................................................................25

Tables

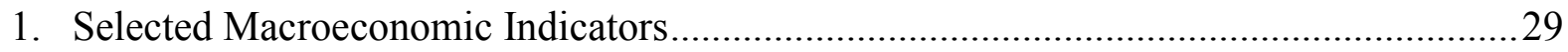

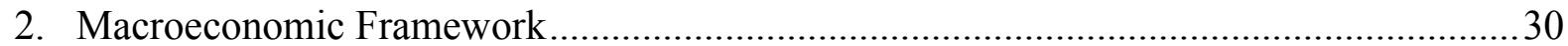

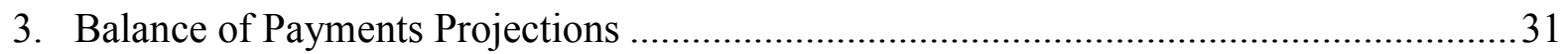

4. External Debt Sustainability Framework .................................................................... 32

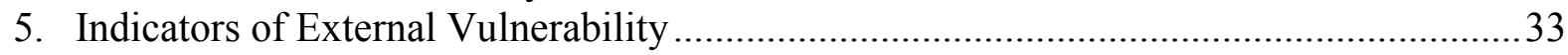

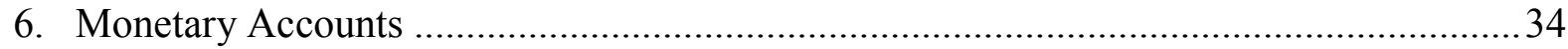

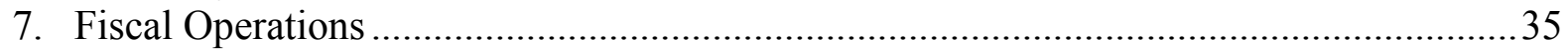

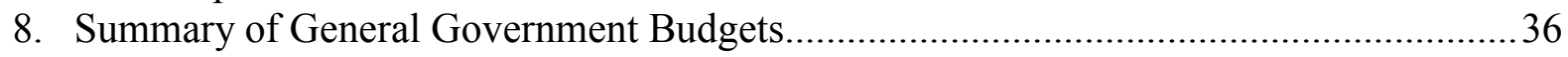

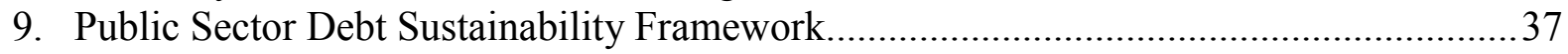

Text Tables

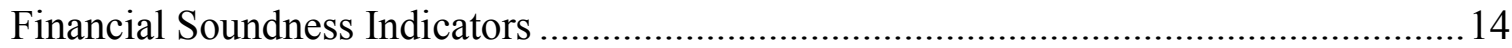

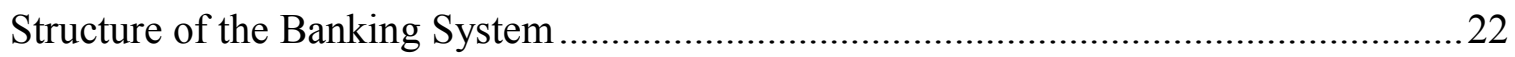

Figures

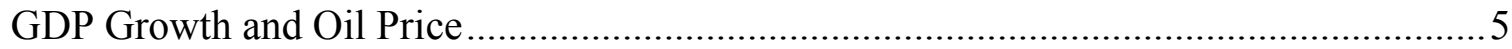

Contributions to GDP Growth.................................................................................. 5

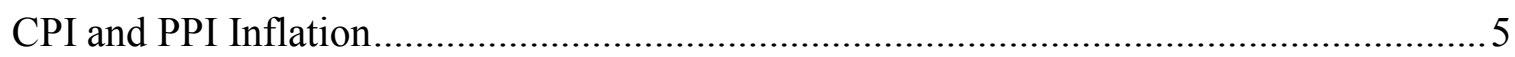

Real Wage and Industrial Productivity Growth ...................................................... 6

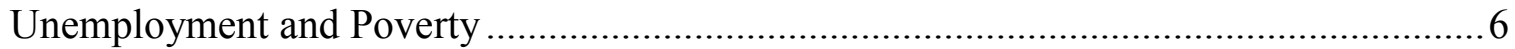

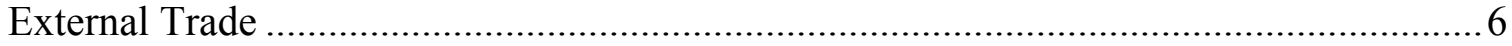




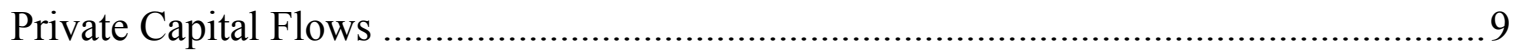

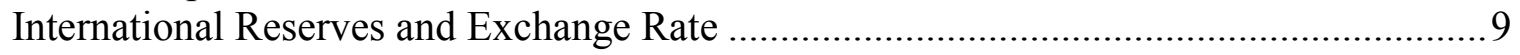

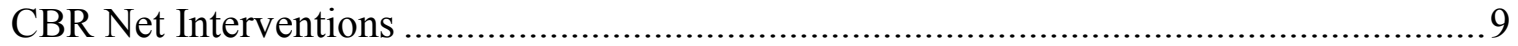

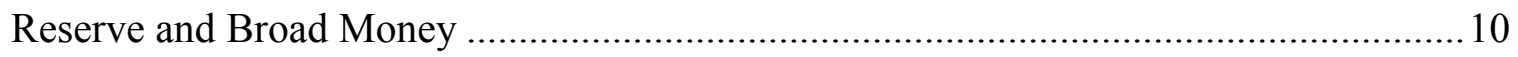

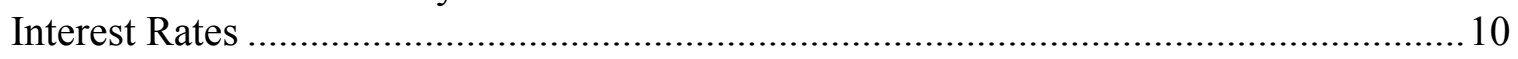

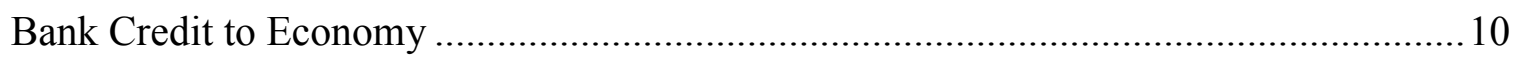

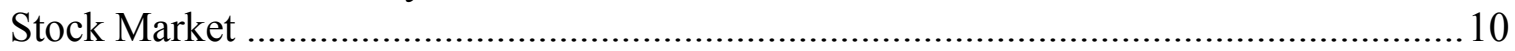

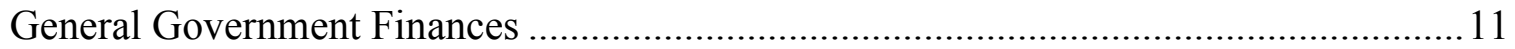

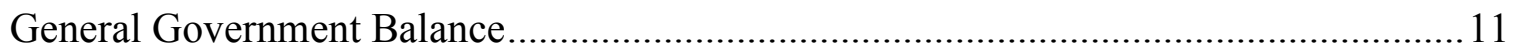

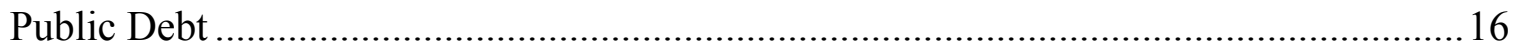

Appendices

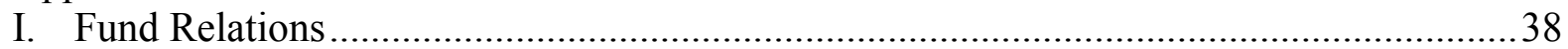

II. Relations with the World Bank Group .................................................................... 41

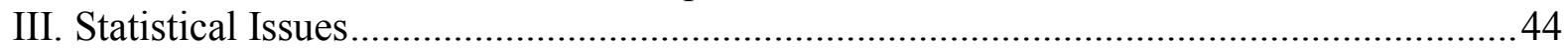

Appendix Table

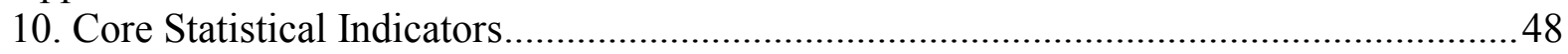




\section{EXECUTIVE SUMMARY}

Background. Growth and the balance of payments have strengthened, driven by high oil prices and increasing investment. However, macroeconomic tensions are rising, with core inflation entrenched and the ruble appreciating briskly in real terms. Tightening labor markets and emerging capacity constraints are adding to inflationary pressures. Monetary policy continues to target both inflation and the ruble, and the authorities plan to loosen fiscal policy by spending more of the oil revenue windfall. Progress on structural reforms has been limited. Recent efforts to press ahead with reforms in the banking sector triggered some deposit runs, to which the central bank responded with a substantial general liquidity injection and extension of household deposit insurance to all banks.

Outlook. Growth is expected to remain robust over the near term, on current assumptions that oil prices will stay relatively high and that negative repercussions from recent events in the banking sector are temporary. The balance of payments should remain strong too, notwithstanding some volatility in short-term capital flows. While external vulnerabilities are likely to remain low, there are significant downside risks, associated not only with the oil price outlook but also with the possibility that further turmoil in the banking system or the handling of the Yukos affair could damage confidence. On planned policies, the pace of disinflation is likely to remain sluggish.

Policy discussions. The discussions focused on the following issues.

- $\quad$ Plans to relax fiscal policy while burdening monetary policy with the task of limiting real ruble appreciation point to increasing policy contradictions. Staff recommended that there should be no further loosening of fiscal policy at this point in the economic cycle. The authorities acknowledged that there were risks, but stressed that these had been weighed carefully against the benefits of higher spending on reforms.

- $\quad$ Monetary policy should focus on reducing inflation, unburdened of exchange rate objectives. CBR officials agreed with staff that fiscal policy is the appropriate instrument for limiting real appreciation. But, with little prospect of fiscal tightening and strong political concerns about real appreciation, the CBR would maintain its dual targeting regime, seeking to reduce inflation while limiting ruble appreciation.

- $\quad$ Recent turmoil in the banking system highlights the need for the CBR to have strong political support and more effective instruments as it seeks to strengthen banking supervision and deal with problem banks. Following years of regulatory forbearance and limited reforms, the authorities recognized that the current favorable macroeconomic environment was likely masking problems that would only emerge when oil prices drop. They agreed with staff that problems need to be addressed now, while the economy is strong and systemic vulnerabilities are manageable.

- $\quad$ Structural reform plans are ambitious but implementation has yet to be initiated. Some senior officials shared staff's concern that high oil prices and strong growth might be causing complacency about reforms. They recognized that, in an environment of lower oil prices, strong growth could only be maintained if reforms are accelerated. 


\section{ECONOMIC BACKGROUND}

1. GDP growth has increased and become better balanced since early 2003. It rose to $7 \frac{1}{4}$ percent in 2003, with all main sectors, except agriculture, and most industrial sub-sectors buoyant. Data for the first half of 2004 suggest that growth remains high, around $71 / 2$ percent, and broadly based. The acceleration in 2003 was mainly due to higher investment, but also to increased oil export volumes. With consumption growth still strong, driven by rising real wages, all main demand components are now providing positive stimulus. The strength of growth continues to hinge on the favorable external environment - notably higher energy prices - but the rise in investment is likely also to have been due to political stability, generally sound macroeconomic policies and some structural reforms, suggesting that GDP is increasingly deriving strength from domestic factors as well.
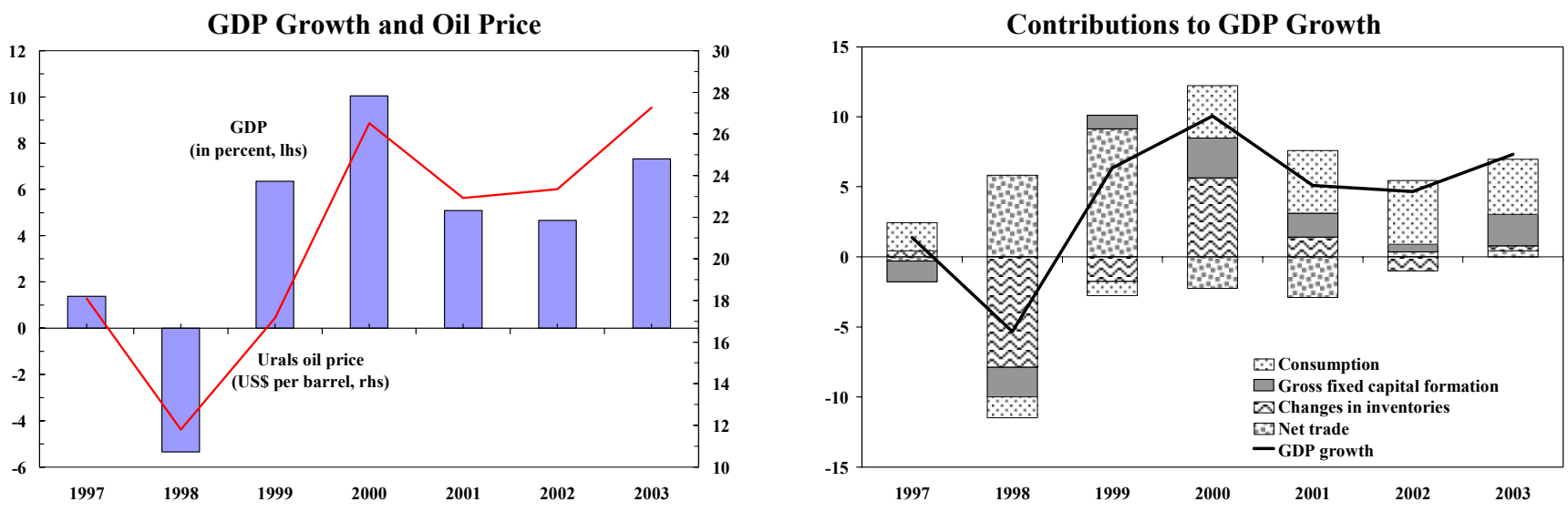

2. Macroeconomic tensions have increased, however, as growth has accelerated and the balance of payments has strengthened:

$\bullet$

Core inflation has become entrenched and the ruble is now appreciating briskly in real terms. Although headline inflation has continued to decline, by 3 percentage points over the past year, this is entirely accounted for by lower increases in non-core elements of the price index, notably administered prices, while core inflation has remained in the 10 11 percent range since mid-2002. ${ }^{1}$ With

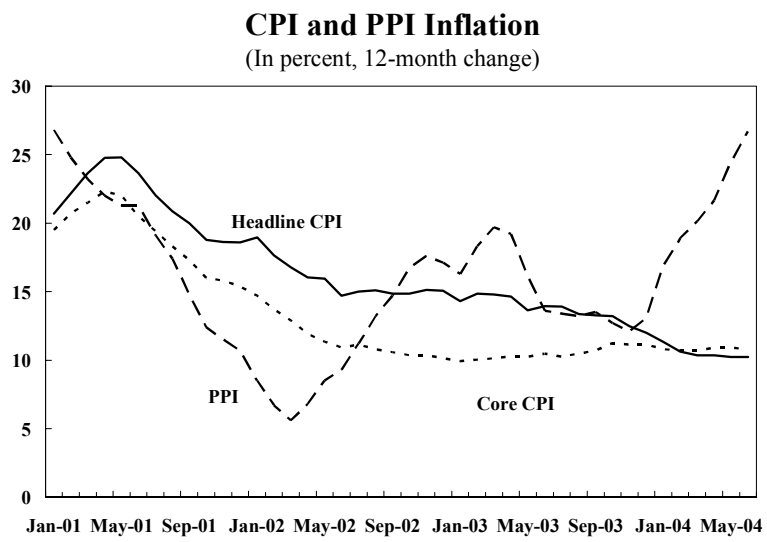

\footnotetext{
${ }^{1}$ Administered prices include prices of gas, electricity, and rail transportation, which are set at the federal level, as well as a range of other prices set at lower levels of government. Core inflation also excludes most volatile food and energy prices, although it includes volatile bread prices.
} 
inflation still high and the ruble broadly stable in nominal effective terms, the pace of real appreciation has increased and is now running at nearly 10 percent year-on-year. The ruble has reached 90 percent of the level prevailing before the 1998 crisis in real terms (Box 1).

- Labor markets are tightening. Real wages have accelerated and are rising faster than labor productivity, and there are notable labor shortages in Moscow and other high growth regions, reflecting very limited labor mobility. Strong GDP growth is no longer translating into a decline in unemployment, although restructuring and labor shedding continue to facilitate a shift in employment from the industrial to the service sector. There are no indications of acute capacity constraints, except in the oil pipeline system, but entrenched consumer price inflation and rising producer price inflation, as the recovery has gained further momentum, point to some tightening.

3. The balance of payments has strengthened further. The impact on imports of rapid domestic demand growth and real ruble appreciation has broadly offset strong growth of oil export volumes and higher oil and gas prices, and the current account surplus has been stable at 8-9 percent of GDP for the past two years. Meanwhile, however, net private capital outflows fell substantially in 2003. This mainly reflected higher short-term financial inflows, primarily a reduction in banks' net foreign assets - by almost $\$ 9$ billion in 2003 - but also higher corporate borrowing and some reversal of foreign currency substitution (Box 2). During the first half of 2004, there were renewed net capital outflows,

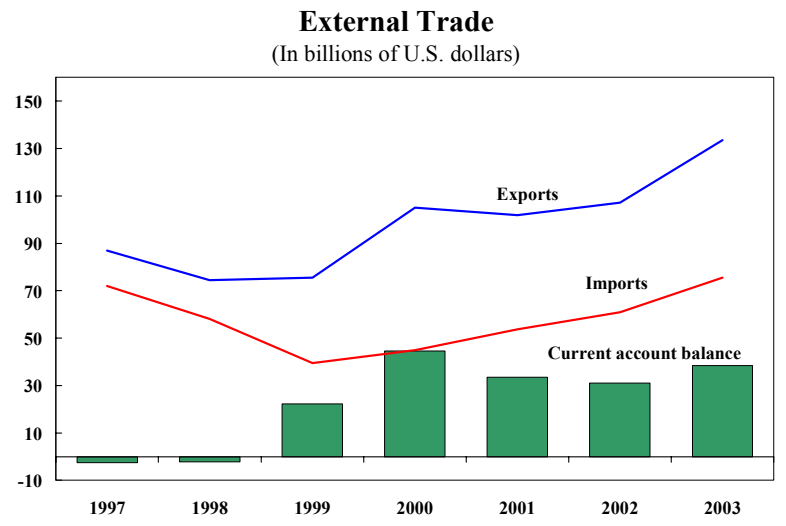
mainly because of a reversal of short-term flows, although renewed reserve accumulation since May suggests that outflows have waned again, even as the banking system was hit by turmoil. While changes in oil prices, upgrades by international rating agencies (to investment 


\section{Box 1. The Russian Economy Since the 1998 Crisis}
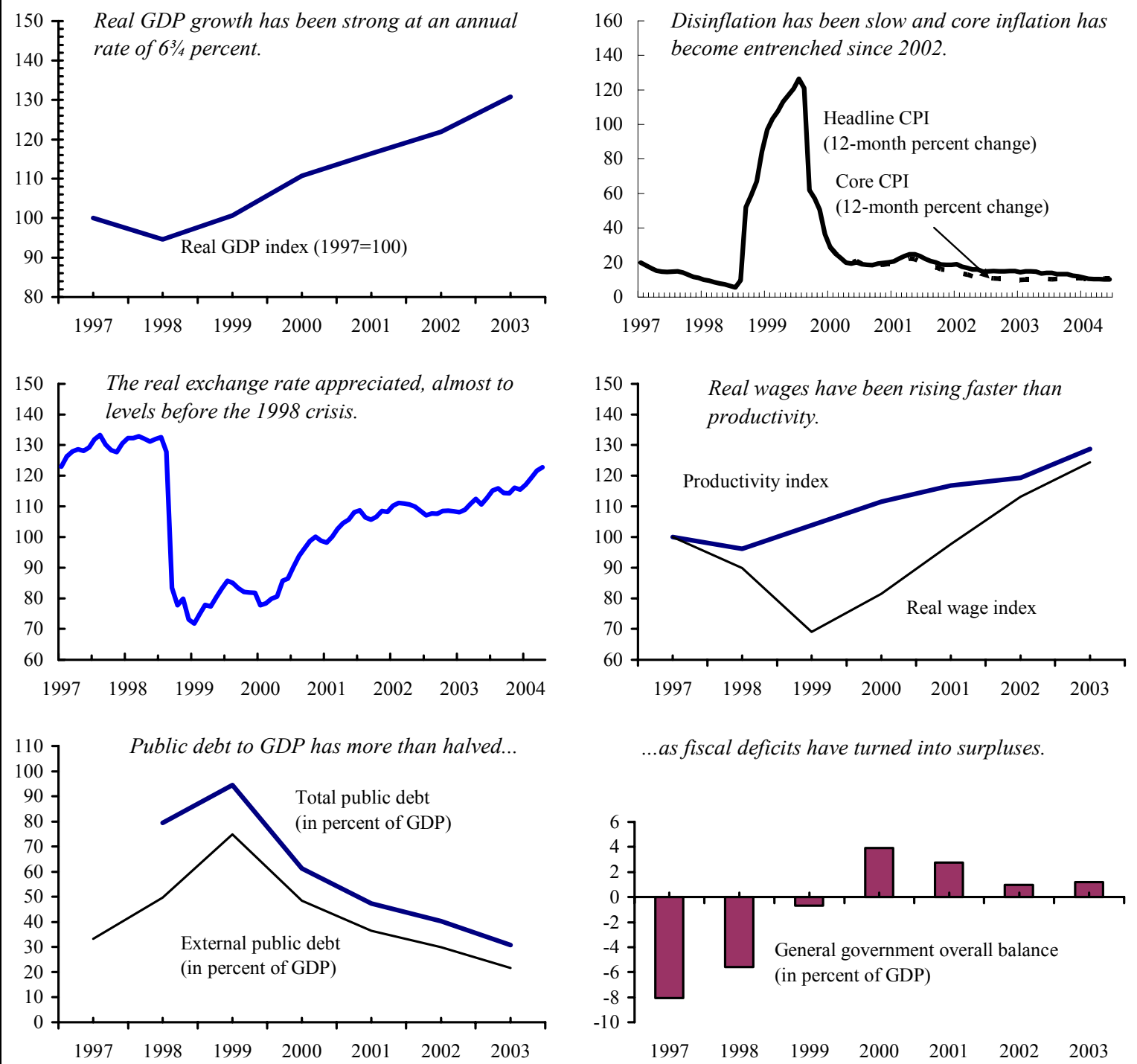

...as fiscal deficits have turned into surpluses.
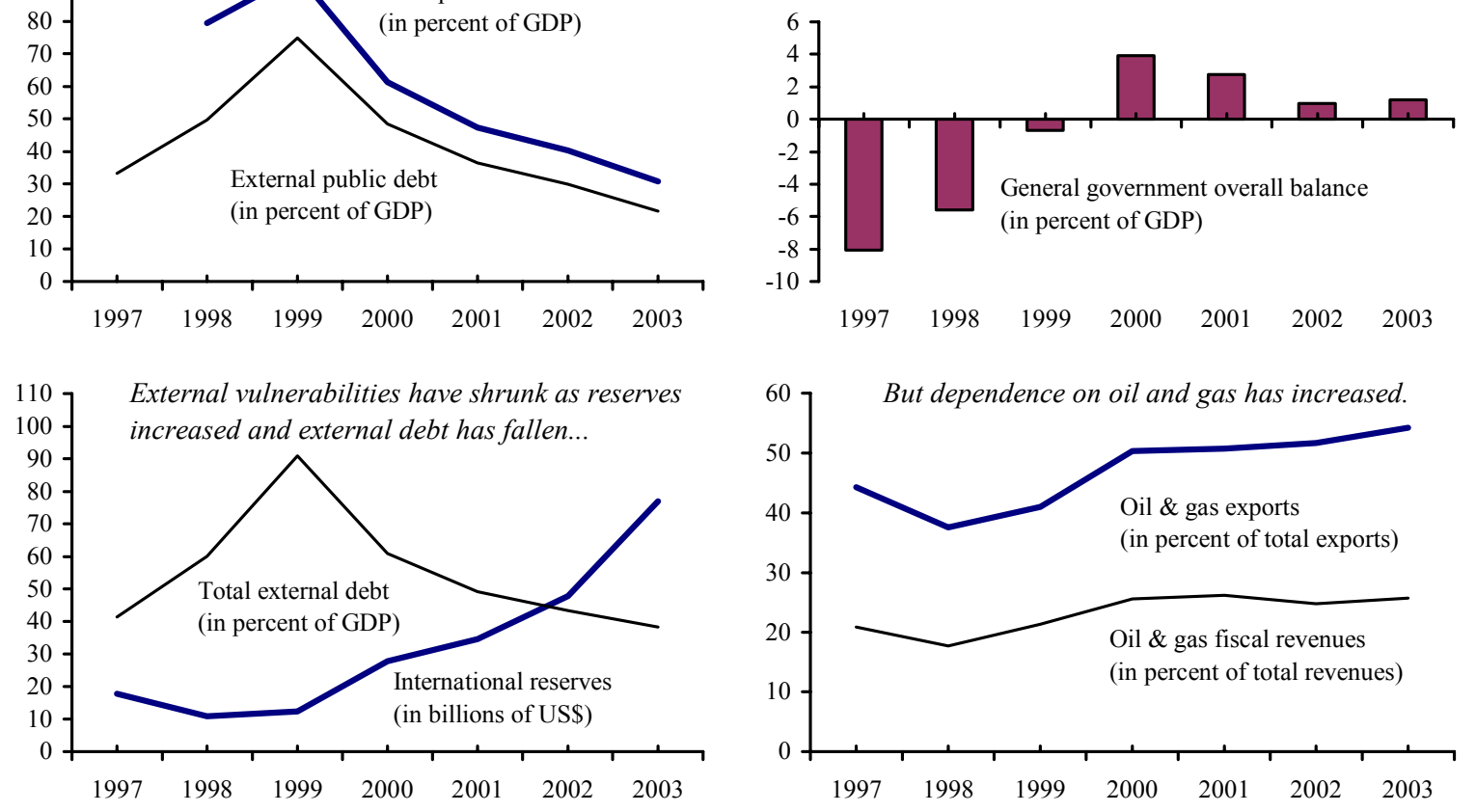


\section{Box 2. Short-term Capital Flows ${ }^{1 /}$}

In 2003, short-term net capital inflows were positive for the first time since the early 1990 s. While large capital outflows continued, they were offset by unprecedented net foreign borrowing by the Russian corporate sector and Russian banks. Foreign direct investment remained small, partly because of the still difficult business environment and partly because of the predominance of offshore transactions for large investments. Many inflows were likely driven by expectations of ruble appreciation and the search for higher-yielding assets as low global interest rates compressed yields for more mature market assets.

Most capital flows continue to be intermediated by the banking system, although non-bank flows increased rapidly during 2003. During the first nine months of 2003, almost 60 percent of capital inflows and a third of capital outflows were mediated by the international or Russian banking system. Despite rapid net foreign borrowing by commercial banks during 2003, they remained net lenders to international banks throughout 2003 and maintained positive net foreign assets for most of 2003 and the first half of 2004. Russian corporates also made heavy use of foreign borrowing, increasingly through bond issues and syndicated loans. While syndicated loans were concentrated in the energy and metals sectors, bond issues covered a wide range of sectors. Equity issues continued to be small, reflecting in part a preference for debt financing.

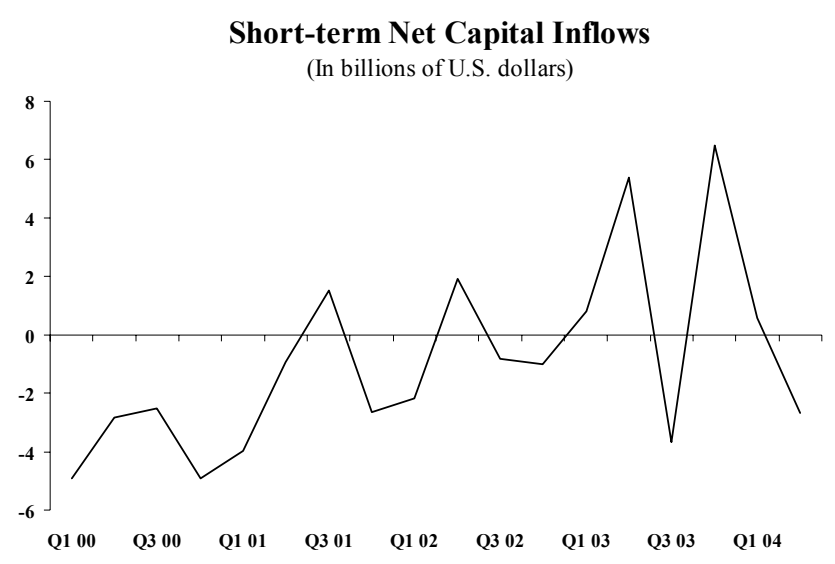

${ }^{1 /}$ See also Selected Issues, Chapter 1. 
grade by one agency) and periodic uncertainty linked to the Yukos affair and future interest rates abroad might have contributed to the volatility in short-term capital flows, the main factor is likely to have been changes in expectations about short-term exchange rate movements caused by changes in the CBR's intervention policy.

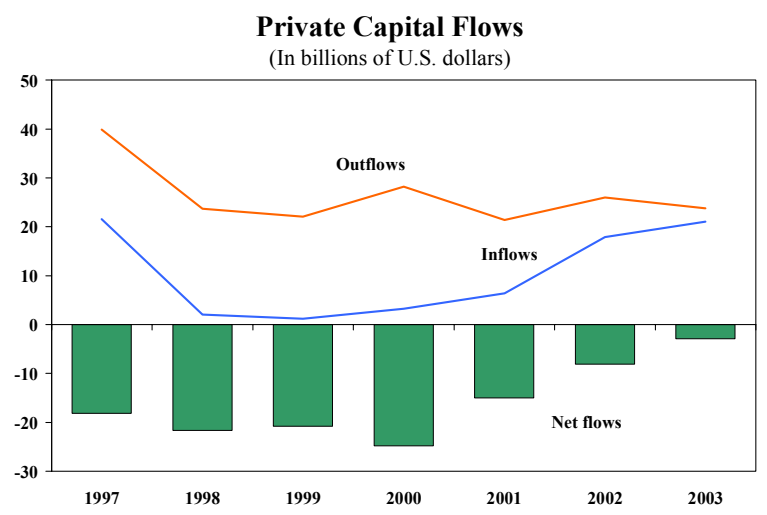

4. The CBR has intervened heavily to slow the ruble's appreciation. Despite changing its intervention policy at the beginning of 2003 - from one of instigating a gradual nominal depreciation to one of allowing some appreciation against the dollar - the CBR has increased its net international reserves by over $\$ 40$ billion since then. A slow predictable appreciation against the dollar in the first half of 2003, and again in the fourth quarter of that year, fuelled expectations about further appreciation and caused surges in short-term inflows and attendant large interventions. Both of these periods were followed by large short-term outflows as the intervention policy was changed so as to inject more uncertainty about nearterm exchange rate movements. Gross international reserves stood at $\$ 88$ billion in mid-2004 (around seven months of imports and more than 200 percent of short-term external debt).
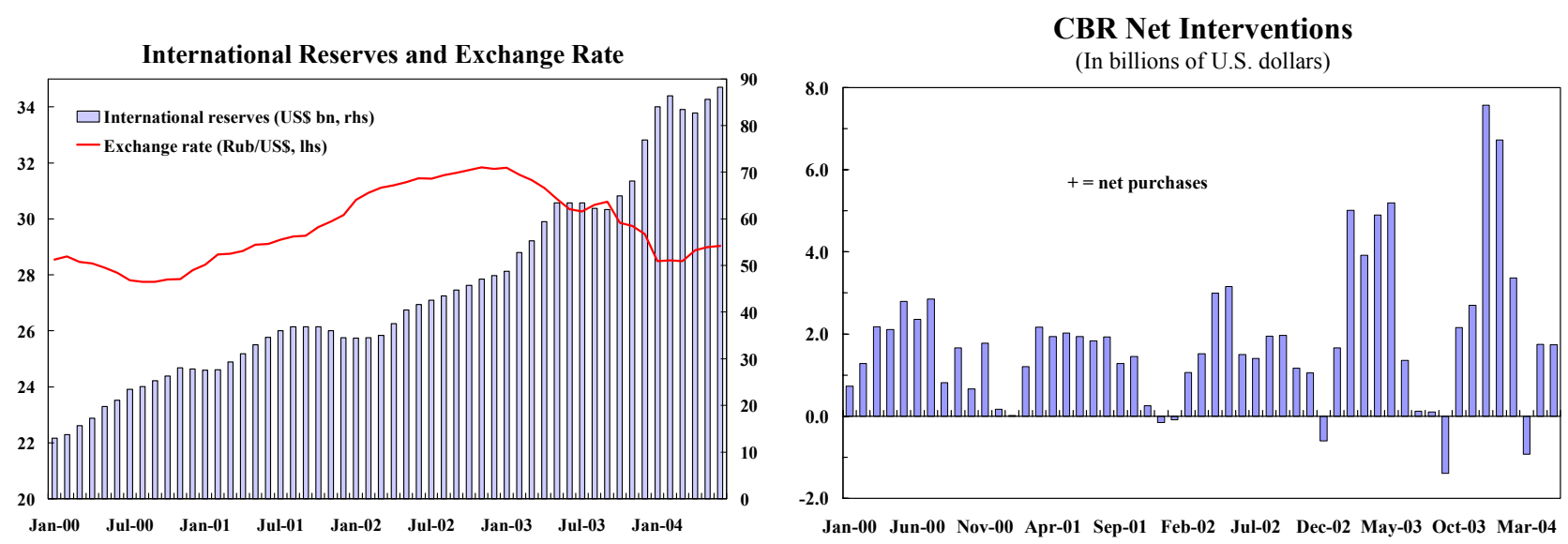

5. Increased interventions have caused a surge in money growth and contributed to core inflation getting entrenched. Base money growth accelerated during 2003 and, despite a recent decline, is still running at around 40 percent year-on-year. The CBR has only sterilized a small part of its intervention, believing that more substantial sterilization would merely attract additional capital inflows, and policy interest rates have been very low since early 2003. The increase in unsterilized interventions has taken place at the same time as a relaxation of fiscal policy has limited the extent to which higher government deposits at the CBR could sterilize interventions. 

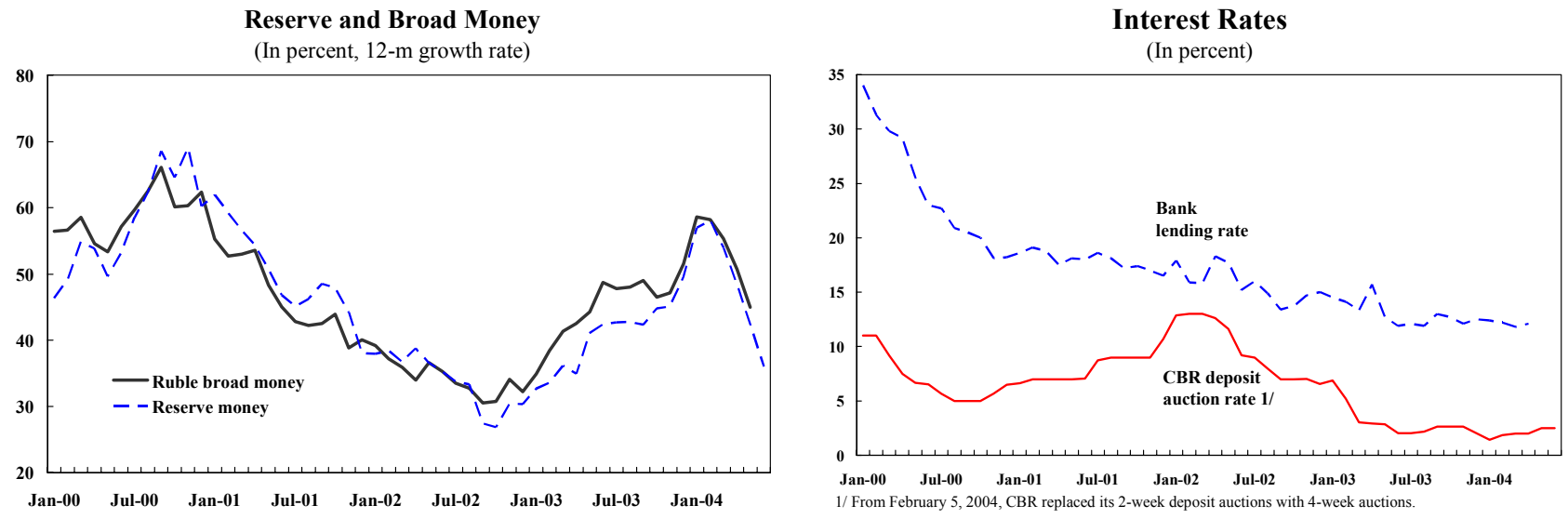

6. Bank credits are rising fast. Broad money is recovering rapidly, with a notable shift from foreign currency to ruble deposits, and with a reduction in foreign currency holdings outside the banking system. ${ }^{2}$ This, together with the large reduction in banks' net foreign assets, has enabled a sharp increase in bank credits to the economy, by about 45 percent during the past 12 months, and over 200 percent since the beginning of 2001 . This surge has coincided with booming real estate and, until recently, stock market prices. However, with broad money and bank credits to the economy still amounting to only 27 percent and 22 percent of GDP, respectively, monetization and intermediation remain low compared to other emerging market economies.
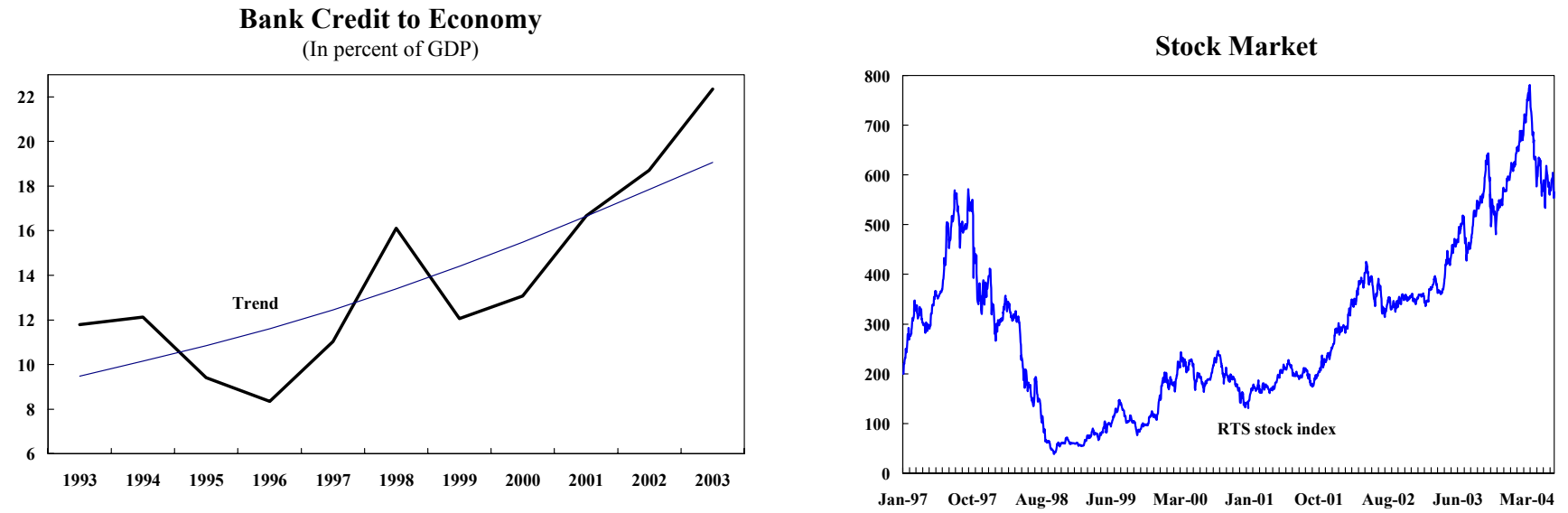

7. Fiscal relaxation continued in 2003. The general government surplus was about 1 percent of GDP, only $1 / 2$ percentage point higher than in 2002 , despite the acceleration in GDP and significantly higher oil taxes. Measured at a constant oil price of $\$ 20$ per barrel, the

\footnotetext{
${ }^{2}$ See also Selected Issues, Chapter 2.
} 
general government deficit increased by 1 percent of GDP, to about $1 \frac{1}{4}$ percent, continuing the relaxation underway since 2001 . This suggests that fiscal policy was notably pro-cyclical in 2003, although the concept of an oil price adjusted fiscal balance only provides an indication of the cyclically-adjusted fiscal position (Box 3). The reduction in non-energy sector taxes by 1 percent of GDP reflects the impact of tax cuts.
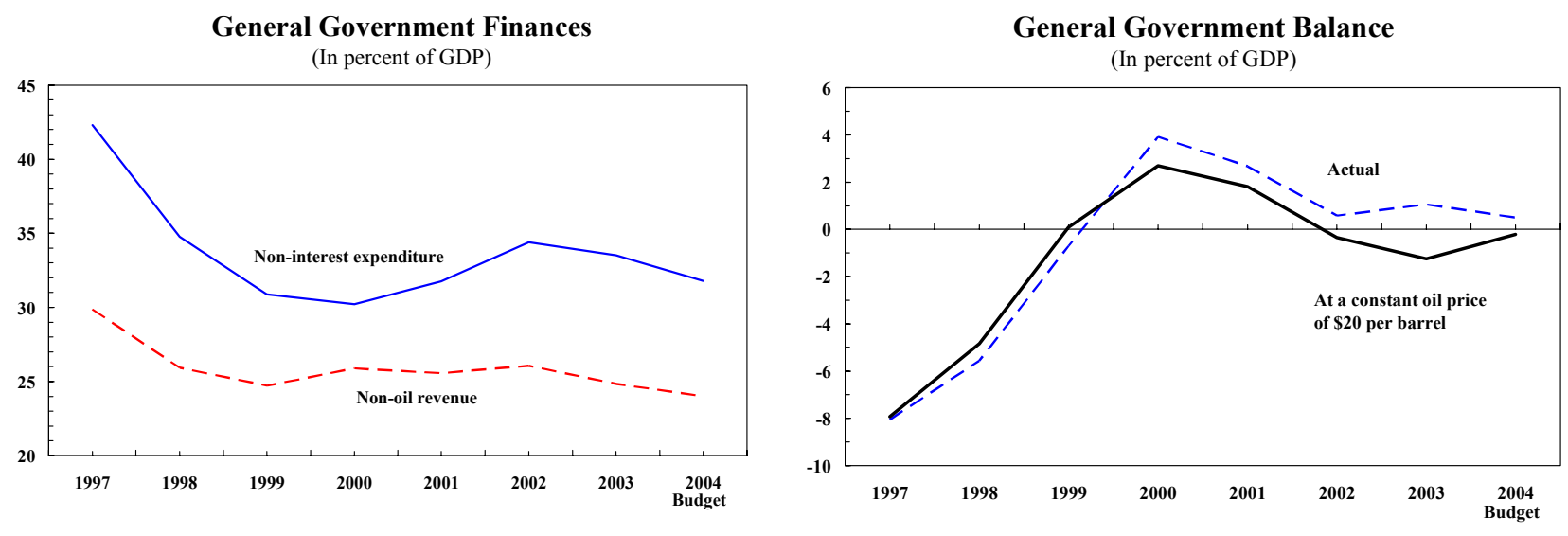

8. The 2004 budget entails some tightening of the fiscal stance, but a renewed relaxation is likely in $\mathbf{2 0 0 5}$. The planned tightening in 2004, of almost 1 percent of GDP, to be achieved by reducing non-interest expenditures, would nearly balance the budget at an oil price of $\$ 20$ per barrel. While, in recent years, the authorities have yielded to within-year pressures resulting from high oil prices to increase spending limits, they expect to be able to resist such pressures this year, partly by pushing the next wage indexation to early 2005 . Their ability to resist has been strengthened by the recent creation of an oil stabilization fund, which accumulates revenues arising from oil prices above $\$ 20$ per barrel. However, the government's draft 2005 budget entails reduced saving of oil revenues and an attendant relaxation of fiscal policy, as discussed in Section II.

\section{There has been only limited progress on structural reforms for two years.}

Reforms of the pension system and the electricity sector were scaled down, while reforms of Gazprom, the public administration, and the social and military sectors effectively stalled. The only major legislation adopted was the introduction of deposit insurance and the liberalization of capital flows. The deposit insurance law aims at leveling the playing field between state and private banks by extending insurance (for household deposits up to Ruble 100,000) to all qualified banks. Banks that do not meet strict prudential eligibility criteria will lose their license to take retail deposits by September 2005. The liberalization of capital flows is far-reaching; the law eliminates the existing system of permits and controls, and empowers the CBR to impose unremunerated deposit requirements on capital flows. The CBR has decided to avail itself of this opportunity by introducing moderate deposit requirements on both inflows and outflows with effect from August 1, 2004, citing the 


\section{Box 3: Oil Price Adjusted Fiscal Balance}

Staff analysis of the direct impact of oil prices on energy taxes suggests that a $\$ 1$ decline in the oil price would reduce revenues by $1 / 3$ percent of GDP. ${ }^{1}$ On this basis, at a Urals oil price of $\$ 20$ a barrel, the general government would have run a deficit of $1 \frac{1 / 4}{4}$ percent of GDP in 2003, compared with the recorded surplus (at the actual Urals oil price of \$27 a barrel) of 1 percent of GDP. This represents an underlying loosening, at constant oil prices, of 4 percent of GDP since 2000.

This calculation does not take account of the impact of the economic cycle on the fiscal balance, estimates of which are hampered by the lack of any normal economic cycles during most of the transition period so far. However, given the strong correlation of GDP growth with the oil price since 1995, it is clear that the above calculation understates the total impact of changes in the oil price on the fiscal balance. Based on estimates, including those of the ministry of economy, that a reduction in oil prices of $\$ 1$ a barrel would reduce GDP in the short term by $1 / 4-1 / 2$ percent, and given that general government revenues are about one third of GDP, a conservative estimate of the indirect impact on the budget of a $\$ 20$ oil price in 2003, via lower GDP, would be in the range $1 / 2-1$ percent of GDP. Thus, the total impact on the budget - direct plus indirect — of a $\$ 1$ change in the oil price could be nearly $1 / 2$ percent of GDP. Figures quoted elsewhere in the text and in tables only take account of the direct impact, for which estimates are relatively soundly based.

${ }^{1}$ The methodology is discussed in a paper by Goohoon Kwon: "Post-crisis revenue developments in Russia," Public finance and Management, Vol. 3, No. 4, 2003. The sensitivity of revenues to oil price depends on the tax structure.

pressures on the ruble to appreciate and the need to protect the still weak banking system from the impact of volatile external flows.

\section{Considerable weaknesses remain in the banking system and the regulatory}

framework. According to soundness indicators, based on Russian Accounting Standards, banks overall have been profitable and are adequately provisioned and capitalized. Asset quality has been improving in tandem with the strong macroeconomic environment.

However, structural weaknesses remain, including an economy and banking system that is highly sensitive to oil prices; concentrated exposures, many to related parties; a nontransparent operating environment, with poor corporate governance and risk management; weak creditor rights; unreliable financial statements; an inadequate bank bankruptcy law, and a history of supervisory and prudential forbearance. Meanwhile, Sberbank continues to dominate the system, and there has been no progress in developing a strategy for its future. ${ }^{3}$

\footnotetext{
${ }^{3}$ See also Selected Issues, Chapter 3.
} 
11. Increased regulatory vigilance in recent months has sparked turmoil in parts of the banking system. The CBR has strengthened enforcement of prudential standards as part of the process of enrolling banks in the deposit insurance scheme and enforcing AML/CFT legislation. As these processes unfolded, some banks have faced liquidity problems arising from depositor nervousness. Since the closure of a bank in May, nine other private bankstwo among the top 25 in terms of assets - have publicly acknowledged liquidity problems and three have been closed. After Guta Bank, one of the top 25, suspended operations because of a deposit run in July, other private banks also experienced runs and the CBR took strong measures to restore confidence, including support for the purchase of Guta Bank by state-owned Vneshtorgbank (VTB), a halving of reserve requirements to $3 \frac{1}{2}$ percent, and immediate extension of deposit insurance to all banks, even those that fail to meet the eligibility criteria for the new scheme. ${ }^{4}$ State-owned banks have been seen as a safe haven during the turmoil among private banks.

12. The prospects for early WTO accession have improved. The main outstanding problems hindering accession appear to have been overcome with the recent agreement between Russia and the EU, including on a phased increase in domestic energy prices. The authorities hope that accession will take place by end-2005.

\section{REPORT ON THE DISCUSSIONS}

13. With signs that strong GDP growth and the favorable balance of payments are causing macroeconomic tensions, and with the new government planning to implement reforms that will be costly to the budget, discussions of macroeconomic policies focused primarily on balancing concerns about short-term macroeconomic risks and the desire to advance reforms. Discussions of other issues were mainly concerned with the risk of serious disruptions in the banking system, including from a drop in oil prices, and with the structural reforms needed to strengthen the economy's ability to sustain rapid growth with lower oil prices. The discussions were timely, as the new government was at the early stages of preparing the 2005 budget and formulating its medium-term reform program.

14. The Fund's policy advice in recent years has focused on the need to reduce inflation to a low and stable rate; gearing fiscal policy to the economic and oil price cycles so as to limit pressures for real ruble appreciation; the need for strong structural reforms to improve the investment climate and limit the economy's dependence on the natural resource sector; and measures to strengthen the supervisory and regulatory framework for banks. Progress in these areas has been mixed, with the rise in world energy and commodity prices leading to pressures for fiscal relaxation, slow progress on disinflation, and a weakening resolve to tackle vested interests opposed to reforms.

\footnotetext{
${ }^{4}$ Deposits in banks that cannot meet the eligibility criteria for the regular deposit insurance scheme will be guaranteed by the CBR, subject to the same terms as the general scheme. Any unrecoverable cost to the CBR will eventually become a charge on the budget.
} 
Russia: Financial Soundness Indicators 1/

(In percent)

\begin{tabular}{|c|c|c|c|c|c|c|c|}
\hline Indicator & 1998 & 1999 & 2000 & 2001 & 2002 & 2003 & Q1 2004 \\
\hline \multicolumn{8}{|l|}{ Capital } \\
\hline Regulatory capital to risk-weighted assets & 11.5 & 18.1 & 19.0 & 20.3 & 19.1 & 19.1 & 18.7 \\
\hline Regulatory Tier I capital to risk-weighted assets & 11.8 & 16.4 & 16.5 & 16.7 & 15.8 & 14.5 & 13.8 \\
\hline \multicolumn{8}{|l|}{ Asset quality } \\
\hline Nonperforming loans to total gross loans & 17.3 & 13.4 & 7.7 & 6.2 & 5.6 & 5.0 & 5.0 \\
\hline \multicolumn{8}{|l|}{ Sectoral exposures } \\
\hline \multicolumn{8}{|l|}{ Sectoral distribution of loans to total loans } \\
\hline Industry & 29.6 & 34.1 & 39.9 & 40.1 & 36.7 & 33.3 & 32.3 \\
\hline Agriculture & 1.0 & 1.2 & 1.4 & 1.8 & 2.2 & 2.4 & 2.8 \\
\hline Construction & 7.7 & 7.1 & 5.7 & 4.2 & 4.4 & 4.4 & 4.2 \\
\hline Trade and public dining & 17.5 & 16.7 & 17.6 & 19.6 & 21.6 & 20.6 & 20.3 \\
\hline Transport and communication & 3.7 & 4.9 & 4.9 & 4.5 & 4.6 & 5.1 & 5.2 \\
\hline Others & 34.4 & 30.3 & 25 & 22.5 & 22.4 & 22.7 & 22.7 \\
\hline Individuals & 6.0 & 5.7 & 5.5 & 7.3 & 8.0 & 11.5 & 12.6 \\
\hline \multicolumn{8}{|l|}{ Regions } \\
\hline Russia & 35.3 & 31.7 & 26 & 37.9 & 41.1 & 54.2 & 47.2 \\
\hline U.K. & 7.5 & 15.5 & 16.2 & 13.5 & 23.4 & 9.0 & 14.4 \\
\hline US & 12.7 & 15.4 & 17.4 & 18.9 & 6.2 & 8.2 & 8.3 \\
\hline Germany & 7.4 & 4.8 & 8.0 & 6.0 & 5.9 & 2.4 & 5.3 \\
\hline Austria & 16.9 & 8.1 & 6.7 & 6.4 & 5.7 & 6.8 & 4.3 \\
\hline France & 1.2 & 3.3 & 3.4 & 2.7 & 1.5 & 1.6 & 3.2 \\
\hline Italy & 0.8 & 3.4 & 4.4 & 2.4 & 1.6 & 1.0 & 2.8 \\
\hline Others & 18.1 & 17.8 & 17.9 & 12.2 & 14.5 & 16.8 & 14.4 \\
\hline \multicolumn{8}{|l|}{ Profitability } \\
\hline Return on assets & -3.5 & -0.3 & 0.9 & 2.4 & 2.6 & 2.6 & .. \\
\hline Return on equity & -28.6 & -4.0 & 8.0 & 19.4 & 18.0 & 17.8 & ... \\
\hline \multicolumn{8}{|l|}{ Liquidity } \\
\hline Liquid assets to total assets & 35.3 & 39.1 & 41.3 & 40.8 & 39.1 & 36.1 & 34.3 \\
\hline Liquid assets to short-term liabilities & 70.0 & 82.4 & 82.9 & 87.4 & 90.6 & 90.4 & 90.9 \\
\hline \multicolumn{8}{|l|}{ Market risk } \\
\hline Net open position in foreign exchange to capital & $\ldots$ & $\ldots$ & 42.9 & 22.6 & 18.5 & 8.4 & 7.7 \\
\hline \multicolumn{8}{|l|}{ Other FSIs } \\
\hline Loan loss reserves to total gross loans & 7.4 & 9.9 & 7.9 & 6.7 & 6.3 & 5.9 & 5.9 \\
\hline Large exposures to capital & 450.2 & 275.7 & 249.4 & 216.1 & 228.6 & 241.0 & 233.6 \\
\hline Interest rate risk to capital & $\ldots$ & $\ldots$ & 2.4 & 4.0 & 6.9 & 9.9 & 12.6 \\
\hline Net open position in equities to capital & $\ldots$ & $\ldots$ & 1.0 & 5.6 & 11.7 & 12.4 & 17.2 \\
\hline
\end{tabular}

1/ Credit and depository institutions. 


\section{A. Outlook}

15. Real GDP growth is likely to remain robust over the near term. On the assumption that oil prices remain relatively high and that there are no adverse jolts to the investment climate, recent trends in the main components of demand are likely to be sustained, except for some decline in the contribution of net exports, reflecting the impact of real ruble appreciation and a slowing of oil export volume growth from exceptional rates over the past two years. Staff projects GDP growth of 71/4 percent in 2004, slowing only slightly to $6 \frac{1}{2}$ percent in 2005 , on the assumption of a Urals oil price of $\$ 30$ a barrel in 2004 , and $\$ 281 / 2$ in 2005 (Table 1). The authorities are somewhat less optimistic, projecting $6 \frac{1}{2}$ percent growth in 2004 and 6 percent in 2005, based on lower Urals oil price assumptions of \$29 and \$26 a barrel respectively.

\section{The outlook is, however, subject to much uncertainty, with notable downside}

risks. In addition to the oil price outlook, uncertainty arises from the risk that recent turmoil in the banking system and concerns among investors about the handling of the Yukos affair could impact negatively on investment and capital flows. While there is little evidence as yet of any adverse impact of the Yukos affair on investment, it has likely contributed to the volatility of capital flows. In addition, the initiation of bankruptcy procedures against Yukos could disrupt oil production, with a possibly significant direct negative impact on exports and GDP. Moreover, sale of Yukos' assets in anything other than a transparent manner, at fair market prices, would be very damaging to confidence. The outlook assumes that the authorities are successful in restoring confidence to the banking system, and that their handling of the Yukos affair does not lead to widespread concerns among investors about the transparency, fairness and even-handedness of the enforcement of laws and regulations. The authorities' assurances in this regard, and their intention to advance structural reforms, underlie the staff's assumption that any negative repercussions of recent events are likely to be temporary.

\section{Growth is assumed to slow over the medium term from its current rapid pace.}

Most studies, including by the ministry of economy, put trend growth at about 5 percent, reflecting estimates that perhaps 2 percentage points of last year's growth was due to exceptionally high oil prices, and assuming steady progress on structural reforms. The staff's medium-term scenario assumes growth will slow to this rate as oil and other commodity prices decline to more normal levels (Table 2). On this view, the economy is presently roughly at potential and would remain on that track over the medium-term.

18. The balance of payments should remain strong. As to the remainder of 2004 and 2005, rapid domestic demand growth and real ruble appreciation are driving strong import growth, but this should be offset by the impact of high oil prices this year (Table 3 ). Although capital inflows will likely be lower than in 2003, reflecting the developments during the first half of the year discussed in paragraph 3, reserve accumulation is still expected to be substantial, at around $\$ 20$ billion this year. Looking to the medium term, as oil and commodity prices return to more normal levels, the current account surplus is likely to decline. However, net private capital inflows should increase over time, reflecting higher 
direct investment as reforms take hold, as well as continued shorter-term inflows, not least because slow progress in reducing inflation is likely to cause continued sizeable interest rate differentials.

19. External vulnerabilities are, therefore, likely to remain low. Public external debt, net of reserves, has already fallen close to zero, compared with $\$ 140$ billion in 1998. Gross public external debt, currently around 20 percent of GDP, is projected to fall below 10 percent by 2007 , while total external debt is projected to stabilize at just under 30 percent of GDP, held up by rising private sector borrowing abroad (Tables 4-5). The authorities reaffirmed their intention to make advance repurchases of their outstanding obligations to the Fund later this year.

\section{On planned policies, the pace of}

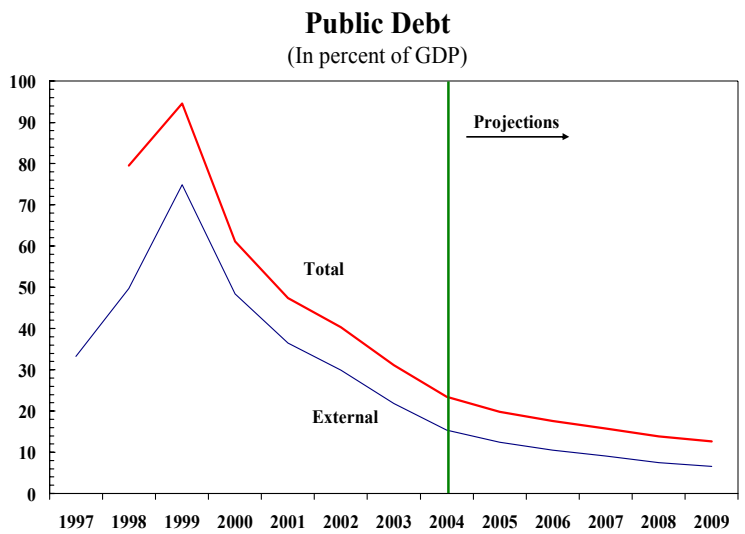

disinflation is expected to remain sluggish, at best. The authorities are targeting headline inflation of $8-10$ percent in 2004 and $6 \frac{1}{2}-8 \frac{1}{2}$ percent in 2005, and expect that real effective ruble appreciation can be limited to 3-7 percent a year. The authorities may continue to meet headline inflation targets, primarily through restraint of administered prices. However, as discussed below, staff believes that without a change in the policies discussed with the mission, the authorities will struggle to lower core inflation substantially while reducing the pace of real ruble appreciation, barring a much sharper reduction in oil prices than currently expected (Table 6).

\section{B. Fiscal Policy}

21. Pressures for fiscal relaxation to finance reforms are increasing. According to ministry of finance officials, the view is gaining ground that Russia should take advantage of the oil tax windfall to accelerate costly reforms, and that this will have no serious macroeconomic implications as long as the budget is in surplus. The government is determined to cut the unified social tax (UST) and launch a major expenditure reform by replacing many existing in-kind benefits — so called "unfunded mandates" — — with monetary benefits, at a cost to the 2005 budget of about 2 percent of GDP. ${ }^{6}$ The government is,

\footnotetext{
${ }^{5}$ Expenditure responsibilities devolved from the federal government to sub-national governments without any identified source of financing. In practice, some of these benefits are financed by enterprises that provide services to certain beneficiaries free of charge.

${ }^{6}$ See Selected Issues, Chapter 4. The UST cut is estimated to reduce revenues of the extrabudgetary funds by $1 \frac{1}{4}$ percent of GDP. The draft budget envisages an increased federal transfer to the pension fund to cover about half of this shortfall. Federal spending will also increase by about $3 / 4$ percent of GDP to finance the monetization of in-kind benefits.
} 
however, resisting pressures for larger tax cuts and higher infrastructure spending. Reflecting significant expenditure savings in other areas, mostly at the local government level, the draft budget for 2005 assumes that the relaxation at constant oil prices will be only about $1 / 4$ percent of GDP. Officials felt that this would not pose macroeconomic problems. Overall, they judged that the proposed fiscal stance carefully balanced macroeconomic risks and the need to facilitate reforms.

22. Less oil taxes will be saved. Officials explained that, whereas all revenues arising from oil prices above $\$ 20$ a barrel are currently being saved in the stabilization fund, only half of such revenues will be saved once the existing cap on the fund of Ruble 500 billion (about $23 / 4$ percent of GDP) is reached. This will happen by mid-2005 under the budget's oil price assumption of $\$ 26$ a barrel, and much earlier if prices remain at current levels. The half that will be spent will be transferred to the pension fund to cover the gap left by the cut in the UST. The other half will be saved outside the stabilization fund, and could be used for early repayment of debt.

23. Staff found that the relaxation could be significantly higher than assumed in the budget. It doubted the realism of the assumed expenditure savings, in particular the assumption that regional and local governments will cut spending by around $1 \frac{1}{2}$ percent of GDP and run a surplus of $3 / 4$ percent of GDP. In view of the still weak framework for controlling spending at lower levels of government, staff argued that sub-national governments should be assumed to balance their budgets, at best. Overall, it expected the draft budget to entail a relaxation of the general government stance at constant oil prices of $1-1 \frac{1}{4}$ percent of GDP in 2005 (Tables 7-8).

\section{Staff argued that fiscal policy should not add stimulus at this point in the} economic cycle. In view of already existing macroeconomic tensions and the favorable outlook for private demand and the balance of payments, fiscal policy should not be loosened. A case could be made for tightening, but staff felt that an unchanged stance would strike an appropriate balance between macroeconomic concerns and the need to advance reforms. Additional measures yielding savings or revenues of $1-1 \frac{1}{4}$ percent of GDP in 2005 were therefore needed. The implication was also that revenues from oil prices above the current benchmark of $\$ 20$ per barrel should continue to be saved in the stabilization fund and that the cap on the fund should be lifted.

25. Ministry of finance officials agreed that the budget entailed somewhat increased macroeconomic risks. They acknowledged that it would be challenging to ensure the assumed expenditure restraint at local and regional levels. Scope for other savings was, however, very limited, and the UST and expenditure reforms could not be scaled back at this stage. The officials reiterated that risks had been weighed against benefits of lower non-oil taxes and expenditure reforms.

26. The authorities expect tax cuts to yield early benefits. Some senior officials dismissed staff's concerns about the draft budget, expecting that the cut in UST would have a stronger impact on the revenue base than assumed in the draft. They also felt that this cut would quickly lead to higher investment and GDP growth. While supportive of cutting the 
UST, staff warned that more optimistic assumptions about the impact on the revenue base are not supported by international experience. It also cautioned that the impact on investment will depend on broader reforms to improve the investment climate. Staff welcomed the efforts to eliminate unfunded mandates, but questioned whether the attendant monetization of in-kind benefits was sufficiently well targeted.

27. There is a need to clarify policy objectives. The increasing support for immediate fiscal relaxation to finance reforms conflicts with the authorities' unwillingness to accept real ruble appreciation. On the current outlook, preventing any real appreciation - as advocated by some officials - would require a benchmark for the stabilization fund well below the existing \$20 a barrel, significantly reducing scope for costly reforms. Staff argued that some gradual real appreciation is inevitable and desirable (Box 4). It acknowledged that this assessment is subject to much uncertainty as it depends on whether the strength of the balance of payments is temporary or permanent, the impact of reforms on competitiveness, and the quality of reforms burdening the budget, among other factors. But, whatever the conclusions about the sustainable pace of real appreciation, there was a need for consistency with the fiscal stance. Relaxing fiscal policy to finance reforms, while burdening monetary policy with the task of controlling the real exchange rate, pointed to increasing contradictions in the policy mix.

28. Fiscal policy is facing important medium-term challenges. The authorities' plans for further reductions in the non-oil tax burden beyond 2005, and the need to mobilize additional resources for important reforms and improvements in social services, suggest that the pressures on limited public sector resources are set to remain high. The outlook for public debt - currently only around 25 percent of GDP and set to decline further-suggests little cause for concern about debt sustainability, even under a scenario with markedly lower oil prices (Table 9). Staff therefore recognized that, once the current cyclical pressures ease, there could be a case for spending more of the oil revenues on carefully elaborated long-term structural reforms. It cautioned, however, that medium-term fiscal loosening should be tempered by the existence of substantial unfunded pension liabilities, contingent liabilities, including those resulting from the recent introduction of deposit insurance, and the need to ensure that fiscal policy does not add to volatility in GDP in what remains a highly oil dependent economy.

\section{Monetary Policy}

\section{CBR officials explained that monetary policy will target headline inflation of} 10 percent by end-2004 and 71/2 percent by end-2005. They expected slower administered price increases to continue to bear down on inflation, and said that the CBR has no target for core inflation. Some senior officials doubted that there would be much progress in reducing core inflation as long as pressures to resist ruble appreciation persist. 


\section{Box 4. Indicators of Russia's Competitiveness}

According to available indicators, Russia's competitiveness remains adequate on a number of measures, although there are some signs of increasing pressures, particularly from rising labor costs.

- While a rebound of Russia's real effective exchange rate following the post-1998 crisis depreciation was inevitable, the rate of increase of both the CPI- and ULC-based REER has declined substantially since 2002; although appreciation has picked up over the past year, it remains well below the growth rates seen from 1999 to 2002.

- Productivity growth has been strong and rising, particularly in the industrial sector. The unit labor cost-based REER has nonetheless risen by more than the CPI-based measure since the crisis, reflecting the rapid recovery of wages following a sharp post-crisis decline in real wages.

Russia: Real Effective Exchange Rate (January 1998=100)

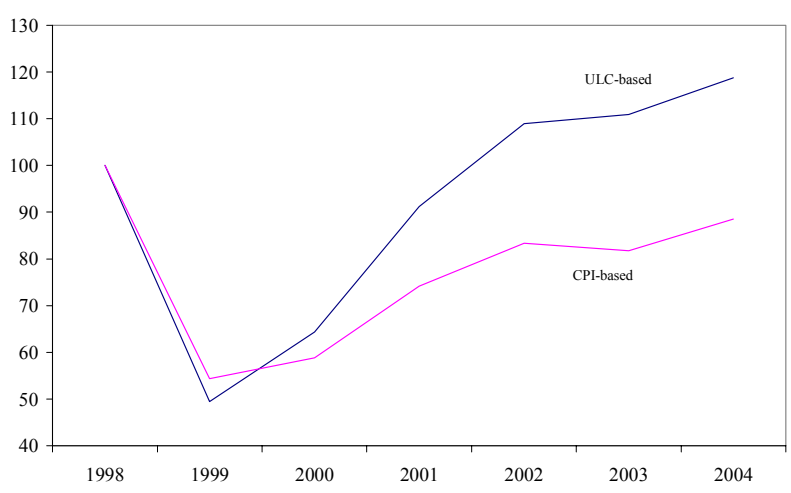

Changes in Wages and Productivity (year on year in percent)

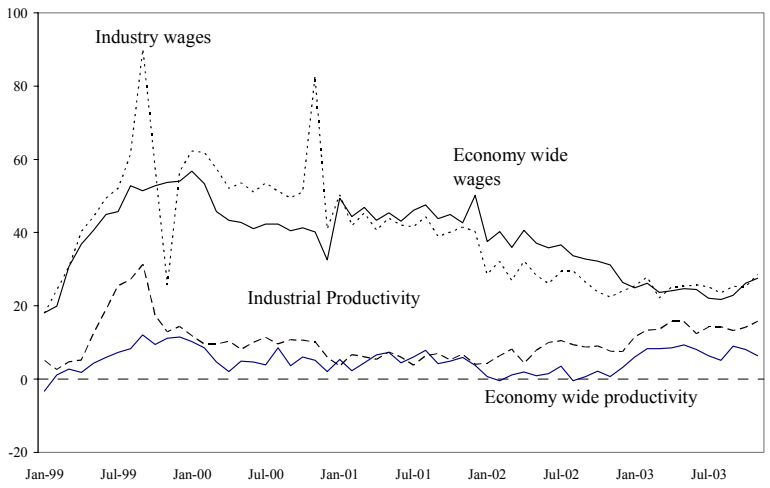

- There are no obvious signs from producer price developments of deteriorating price competitiveness, although profitability may have declined as costs have risen. Comparing sectoral to overall producer prices, the evidence suggests that while relative prices of tradable commodities have gone up (reflecting increases in world commodity prices), those of manufacturers have not, and even those of construction (a classic nontradable) have remained below the average. This suggests that cost pressures associated with the commodity price boom are not being passed on to prices of nontradables and noncommodity exports.

- Despite real exchange rate appreciation, Russia has broadly maintained its share of nonoil exports in world markets, while increasing its share of total world trade.

Ratio of Sectoral to Economywide PPI (January 1998=100)

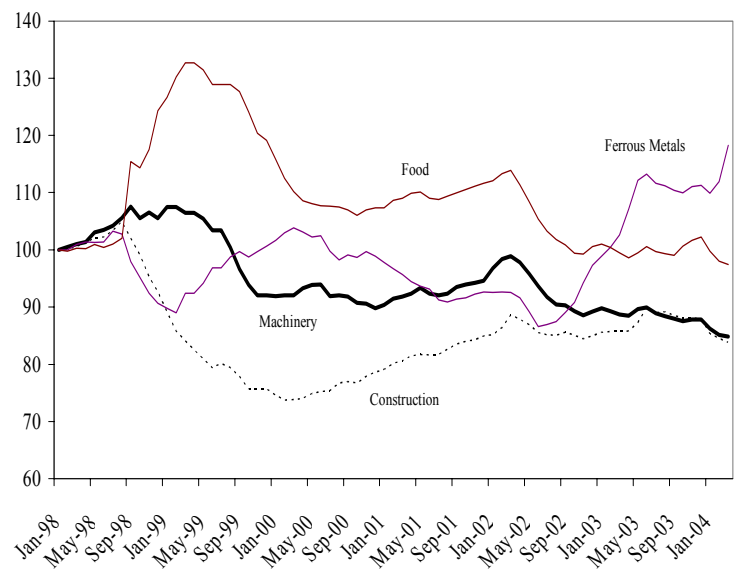

Russia's Exports Market Share of World Imports (1998=100)

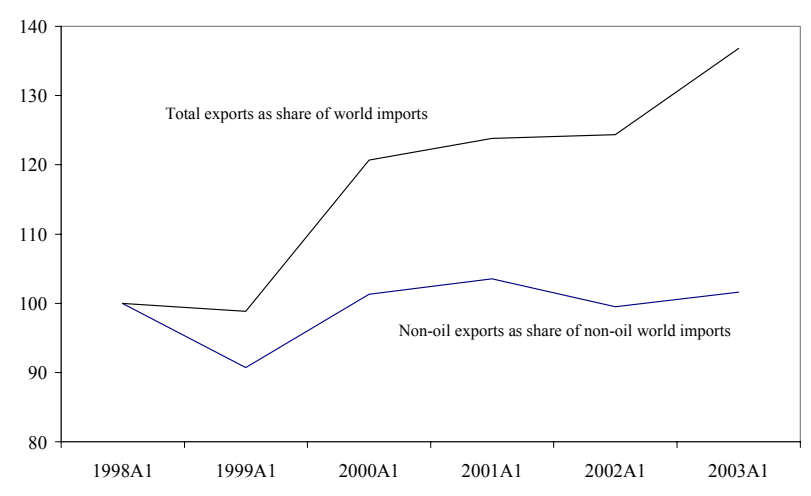


30. The CBR will continue the dual targeting policy of seeking to reduce inflation and stem ruble appreciation. CBR officials acknowledged that monetary policy could resist real ruble appreciation only in the short term, although they took this to be longer than did the mission; that the pressure on the CBR in this regard had been a main reason for the slow progress in reducing inflation; and that a fiscal tightening would be the appropriate instrument for pursuing real exchange rate objectives. However, with little prospect for such a tightening and considering political concerns about real ruble appreciation, the CBR could not accept staff's recommendation to give priority to the inflation target, and to reduce or cease interventions and allow nominal appreciation if interventions threatened the inflation target. Thus, while monetary policy would target some further reduction in inflation, the exchange rate objective would not be subordinated to the inflation target, and the official monetary policy guidelines for 2005 would likely again include an explicit limit for real ruble appreciation as a target for monetary policy.

31. There is limited scope for sterilization. CBR officials argued that sterilization would be largely ineffective in the current situation, as the attendant upward pressure on interest rates would increase inward capital inflows. The mission saw somewhat more scope for sterilization but agreed that this would not be an effective instrument on a large scale.

32. In view of these limitations, CBR officials believed that fiscal relaxation would make it difficult to meet the inflation target. They felt that the proposed relaxation of fiscal policy assumed in the draft 2005 budget was relatively modest - the best that could be hoped for in the current policy environment. But they were concerned that the weakening of the stabilization fund mechanism meant that there would be less of a safeguard against spending higher-than-expected oil revenues. This was a problem since the oil price assumption in the budget was conservative, suggesting that revenues might well be higher than budgeted. In the event that such revenues were spent — or if, as staff warned, spending at regional and local levels was likely to be higher than assumed in the 2005 budget - the end-2005 inflation target might not be met.

33. Staff felt that monetary policy was too accommodating of inflationary pressures from fiscal relaxation. On planned policies, such pressures would intensify, unless oil prices fell significantly from recent levels. Staff believed that the cost to the economy of high inflation was not sufficiently recognized - notwithstanding President Putin's recent call for lower inflation - and that the cost of appreciation was exaggerated. With some real appreciation inevitable, staff argued that the choice for monetary policy is whether this should take place through higher inflation or nominal ruble appreciation. Staff urged the CBR to take advantage of the disinflationary impact of nominal appreciation to set core inflation on a more ambitious downward course. But the pace of disinflation was less important than the commitment not to let the inflation target give way to exchange rate considerations. Staff called for the CBR to focus on core inflation-although it might continue officially to target headline inflation - and urged that administered prices not be used to control inflation. Continued administered price restraint could not be sustained without seriously threatening reforms of the natural monopolies. 
34. CBR officials believed that nominal ruble appreciation would encourage capital inflows. They noted that the two episodes of large inflows last year had occurred during periods when the ruble had been appreciating. Staff argued that these had been periods when a controlled slow and steady nominal appreciation had in effect eliminated short-term exchange rate uncertainty, encouraging speculative bets on ruble appreciation at a time when high domestic interest rates were already attracting inflows. Making clear to the market that monetary policy would be firmly focused on reducing inflation would increase short-term exchange rate uncertainty and so discourage speculative flows. But, with the balance of payments fundamentally strong and the still high rate of inflation implying that interest rate differentials would be large for the foreseeable future, staff warned that fundamentals pointed to continued pressures for medium and long-term capital inflows. This was yet another argument for faster disinflation.

35. Unremunerated deposit requirements will be imposed on capital flows. CBR officials were determined to avail themselves of the right under the new foreign exchange law to invoke such requirements. While they agreed with the law's objective of liberalizing capital controls, deposit requirements were needed to control inflows of volatile short-term capital to weak banks. They would also help stem ruble appreciation.

36. Staff questioned the effectiveness of deposit requirements. While appropriate as a transitional measure from the system of permits and controls, the experience of other countries suggests that the main result of such requirements is to raise the cost of capital, especially for small and medium-sized enterprises. Their impact on inflows is transitory, at best, as markets quickly learn how to evade them. They should, therefore, be seen only as a temporary measure, reserved to deal with exceptionally large inflows, and not as a substitute for a more flexible exchange rate policy. Staff agreed with concerns about inflows to weak banks, but argued that strong banking supervision was the more effective instrument in this regard.

37. CBR officials confirmed the intention to move to inflation targeting over the medium term. The necessary conditions for doing so-including technical requirements identified by MFD - were likely to be in place in 2-3 years, at the earliest.

\section{Financial Sector Vulnerabilities ${ }^{7}$}

38. The CBR is determined to enforce stricter prudential standards. CBR officials stressed that the recent closure of a small bank reflected this - it was the first closure since the 1998 crisis of a bank that had not already defaulted. The forthcoming comprehensive review of banks wanting to join the new deposit insurance scheme and the enforcement of new AML/CTF legislation would provide an opportunity to implement stricter standards.

\footnotetext{
${ }^{7}$ The mission took place soon after the CBR's closure of a bank for violation of AML legislation, and the initial problems that arose in this regard were discussed during the mission. The acute turmoil, precipitated by the closure, occurred after the mission and was discussed with the authorities by staff of the Fund's Moscow Office.
} 
While many banks that did not meet such standards would be able to take corrective actions or merge with stronger banks, CBR officials expected additional closures.

39. The banking system faces increasing risk. CBR stress tests confirm that credit risks have increased, not least because of recent rapid credit growth, as well as the larger exposure to oil price related risk and the economy's dependence on such prices. They found that a shock as severe as the 1998 crisis would result in losses of 4 percent of GDP, based on end2003 data; the FSAP test on the basis of end-2001 data had estimated losses of 3 percent of GDP. Officials agreed with staff that liquidity risk has also increased. While liquidity remains high for the system as a whole, the lack of an effective interbank market, of assets that can serve as collateral, and of transparency about ownership of banks and their activities mean that individual banks may be vulnerable to depositor nervousness, as demonstrated by recent events.

40. CBR officials believed, however, that systemic and macroeconomic vulnerabilities are limited. They noted that the monetization of the economy is still relatively low. Moreover, about $2 / 3$ of household deposits are with CBR-owned Sberbank and a few other state-owned banks, which enjoy a government guarantee of their deposits and have generally been viewed as a safe haven for depositors in times of turbulence, as during the recent turmoil. They also noted that external vulnerabilities have declined to low levels: the public sector's debt, net of foreign reserves, is close to zero, and the corporate sector's debt is also limited, as it regained access to markets only a few years ago.

\section{The recent turbulence points to the urgent need} to sharpen the instruments available for addressing banking sector problems, according to CBR officials. Staff agreed that, while the CBR's recent measures had calmed the situation, the instruments used were relatively blunt. The new interim deposit insurance law had helped to restore confidence, but it entails some moral hazard, and its stabilizing role will be undermined if payouts to depositors are not rapid. CBR officials stressed the need for passage of amendments to the bank bankruptcy law, to provide for more certain and speedy resolution processes and so allow the CBR to intervene effectively with minimum implications for confidence in the system. Staff also agreed with officials about the need to broaden the range of eligible collateral to facilitate the provision of targeted liquidity to sound banks experiencing deposit runs. More generally, staff noted that the episode demonstrated the importance of the CBR being transparent when closing banks and expeditious when faced with negative consequences.

\section{Staff was concerned that recent events might lead to continued regulatory}

forbearance. It felt that there had only been very limited progress in implementing banking reforms since the 1998 crisis, notwithstanding the recent steps to strengthen enforcement of 
prudential norms, and worried that high oil prices and strong growth could be masking longstanding problems. It stressed the importance of tackling the problems now, while they were still manageable, and while the economy was strong and there were resources available to recapitalize banks if necessary. International experience had shown that, if unaddressed, the problems would only get bigger. The CBR would need the full support of the government in exercising its mandate to strengthen supervision, notably in the context of reviewing banks' applications for participation in the deposit insurance scheme. Staff reminded the CBR that this had been seen as the cardinal mechanism for strengthening the banking system, and regulatory forbearance during the process would seriously increase the risks of a major crisis in the future. In this regard, it was worrisome that some recent statements by officials from other parts of government raised doubts about the broader political support for the process.

43. Medium-term reforms need to be accelerated. Priorities include moving to riskbased supervision, improving governance and transparency of bank ownership, and adopting International Financial Reporting Standards. CBR officials noted that these are all reflected in the authorities' medium-term action plan. While acknowledging that the plan was generally well focused, staff expressed concern that it did not give priority to the development of a strategy for state-owned banks, notably Sberbank. While these banks have been a stabilizing force by acting as safe havens during periods of turmoil, they are subject to many of the same concerns regarding transparency and governance as private banks. It would be highly regrettable if periodic bouts of nervousness about the soundness of private banks, combined with the absence of any strategy for the state-owned banks, led to a consolidation of the dominant position of the state-owned banks and stifled the development of a more dynamic and competitive banking sector.

\section{E. Structural Reforms}

\section{The authorities intend to undertake a broadly-based acceleration of reforms.}

Among the main priorities are general administrative reforms and comprehensive reforms of the health, education, housing, and military sectors, in addition to the tax and banking reforms discussed above. Ongoing reforms of the natural monopolies also remain high on the agenda. Officials of the ministry of economy and trade explained that the new government had decided on its broad priorities, but was still in the process of elaborating its programs and was not ready to discuss details, including timing of key steps, with the mission.

45. Officials explained that the overarching objective is to reduce dependence on oil by improving the investment climate, beginning with public sector reforms. The public sector's large claim on resources and still pervasive interference in the economy, not least at local and regional levels, remain serious deterrents to private investment, particularly for small and medium-sized enterprises. The authorities are, therefore, giving priority to reforms of this sector, focusing increasingly on expenditure reforms now that the main tax reforms are nearing completion. General administrative reforms are particularly important. They involve streamlining at all levels of government, elimination of overlapping functions, and a general reduction in the role of government in the economy. The reforms of specific sectors are intended to address a wide array of problems. Common to these reforms is the 
establishment of performance targets and a shift to performance based budgeting. Some of these reforms will be politically very difficult, not least because they involve eliminating provisions establishing general entitlements to housing and social services, provisions left over from central planning and unsuitable to a market economy. (Structural fiscal reforms are discussed in Box 5.)

46. Other parts of the reform program will also improve the investment climate. Housing reforms, including development of the mortgage market, are important for labor mobility, the lack of which produces large regional income inequality and limits potential GDP growth by causing regional labor shortages. ${ }^{8}$ Reforms of the banking sector — as discussed aboveare key to improving what, despite recent increases, is still a relatively low level of financial intermediation, to the detriment of small and medium-sized enterprises. The drive for early WTO accession will catalyze key reforms, promote competition and reduce rent-seeking. On the strength of this broad-based acceleration of reforms, officials believe that Russia would be on track to meet President Putin's challenge to double GDP in ten years.

47. Staff welcomed the basic thrust of the government's reform program, especially its focus on the investment climate, but was concerned about the lack of specificity and in particular about the lack of support for implementation. It broadly shared the authorities' views of priorities, especially the focus on reforms of government to reduce the public sector's interference in the economy, including corruption. But, stressing that several of the most important reforms in this area remained to be elaborated, staff worried that the process of preparing reforms for implementation could be lengthy, since this would be politically and technically difficult. In this regard, staff noted that most of the reform objectives on the government's agenda are not new, but that preparation of reforms or implementation of those that had been prepared and approved have been stalled for some time because of resistance from vested interests. In some areas-like reforms of Gazpromthere appeared to be no agreement on the basic concept, and in others-like reforms of military, housing, education and health sectors - there was agreement on broad objectives but not on detailed plans. In still other areas - like pension and electricity reforms - original plans were being scaled back or subject to protracted implementation periods. Overall, there had been very limited progress during the past two years, and staff worried that high oil prices and robust growth were causing complacency about reforms.

48. Russia's trade regime remains moderately open. Its average tariff rate is about 11 percent. Officials informed staff that bilateral negotiations regarding WTO accession had been completed with partners accounting for three-quarters of trade, but issues relating to market access for automobiles, aircraft and agricultural products were outstanding with remaining countries. Liberalization of the services sector also remains an outstanding issue. Staff welcomed the progress on WTO accession, and urged the authorities to resist opposition from sectors seeking to maintain protective barriers by unduly prolonging

\footnotetext{
${ }^{8}$ See Selected Issues, Chapter 5.
} 


\section{Box 5: Medium-term Structural Fiscal Reform}

Fiscal reforms play a key role in the authorities' ambitious long-term strategy to diversify the economy and double GDP in ten years. To achieve these objectives, the authorities plan to:

- Cut the tax burden on the non-oil sector by about 1 percentage point of GDP a year for the next few years. The authorities believe that redistributing the tax burden from the non-oil to the oil sector will promote economic diversification;

- Increase taxation of oil sector rents associated with exceptionally high oil prices; a policy of saving windfall oil revenues will play a stabilizing role, as federal fiscal revenues become increasingly dependent on oil;

- $\quad$ Rationalize public expenditure to eliminate the remaining legacy of subsidies and inefficiency.

This strategy, which the staff broadly supports, requires measures in the fields of tax and expenditure policy, fiscal federalism, and quasifiscal activities.

\section{Revenues}

Unified social tax is a regressive tax, which is particularly burdensome to small and medium-sized enterprises. The authorities have decided to cut the top rate from 36 percent to 26 percent starting next year, at an estimated cost of $1-1 \frac{1}{2}$ percent of GDP. While the reduction is welcome, it is important that this does not threaten the sustainability of the pension system.

VAT. The authorities plan to unify the rates (currently 18 percent and 10 percent), probably at 16 percent, in 2006 or 2007 . The unification of the rate will reduce distortions and simplify tax administration. However, staff has cautioned against further rate reductions, arguing that the focus should be on cutting other less efficient taxes.

Oil taxes. The authorities have increased the marginal rates of export and extraction taxes when the price of Urals oil is above $\$ 25$ a barrel, effective in 2005.

Tax administration. Poor rules on transfer pricing are a key weakness of tax administration, especially in the oil sector. An amendment to the tax code is needed to eliminate abuses.

\section{Expenditure}

The authorities' long-term goal is to reduce the size of the government and rationalize expenditures. The goal is commendable, given that the legacy of the command economy is still present in many areas.

Expediting civil service and public administration reforms is essential to improve governance and raise the efficiency of public expenditure, and should be a top priority. The government has started a sweeping reform of the public sector by reorganizing several ministries and agencies, but a huge amount of work is still ahead.

Reforms in the military, health, and education sectors are urgent to improve the efficiency of services.

Reforms of energy pricing are long overdue, to reduce quasi-fiscal activities and promote reforms throughout the economy. While the authorities are committed to increase domestic gas and electricity prices over the next few years, staff is concerned that the pace might be too slow, in part because the authorities see restraint of administered price increases as a way to reduce headline inflation.

Fundamental decisions are need to ensure the long term sustainability of the pension system, in view of the projected aging of the population.

State-owned housing and subsidized communal services companies are inefficient and financially nonviable. Reforms in this area are necessary to rationalize public expenditure, especially at local government level. Moreover, housing reforms would reduce obstacles to intra-regional labor mobility.

\section{Other reforms}

Intergovernmental relations. Expenditure responsibilities among different layers of government remain inefficient and nontransparent. A major reform is underway.

The plan to reduce unfunded mandates and monetize some in-kind benefits is an important step toward making public subsidies more transparent. It needs to be accompanied by a hardening of budget constraints of public enterprises providing the services, to ensure fiscal neutrality.

Budget process. The government has recently started a reform of the budget process, which aims to improve efficiency in the formulation and administration of the budget, including through the introduction of performance-based budgeting.

\section{Overall evaluation}

While the staff broadly supports the strategy, it is concerned that strong growth and high oil prices may weaken the resolve to press ahead with these and other reforms. It considers that broad structural reforms and not redistributive tax cuts are the best way to promote economic diversification and sustained growth. In line with the conclusions of the recent fiscal transparency ROSC, it would also like to see a higher priority given to reforms of major public enterprises and the reduction of associated quasi-fiscal activities. 
transition periods before being exposed to foreign competition. The authorities explained that Russia is also pursuing liberalization within the Eurasian Economic Community (consisting, besides Russia, of Belarus, Kazakhstan, Kyrgyz Republic, and Tajikistan), although the customs agreement is expected to come fully into force only after WTO accession. Staff reminded the authorities of the need for speedy removal of all exchange restrictions subject to Article VIII.

\section{StafF APPRAISAL}

49. Russia's economic situation is good, but handling growing tensions will be a challenge. GDP growth is high and is becoming broader based and better balanced; employment and incomes are rising; and key social indicators are improving. With oil prices likely to remain high, the outlook is good, provided the authorities are forceful in addressing recent problems in the banking system and their handling of the Yukos case does not damage the investment climate by raising increasing concerns about the transparency, evenhandedness, and political impartiality of the judicial and regulatory system. With these important caveats, the challenge to macroeconomic policies will be to deal with tensions associated with high growth and a strong balance of payments.

50. Contradictions in macroeconomic policies appear to be rising. They have been prevalent for some time: fiscal relaxation has exacerbated the pressures for real ruble appreciation arising from the exceptionally strong balance of payments, while monetary and exchange rate policies have sought to resist such pressures, at the cost of entrenched inflation. The current drive for a further fiscal relaxation to finance reforms, while the CBR remains committed to resisting appreciation, suggest that contradictions are rising. Whether this will cause already existing macroeconomic tensions to intensify will depend on the environment, notably on oil prices and private demand. Under the current outlook, staff is concerned that planned policies will permit little if any progress in reducing core inflation and that real ruble appreciation will continue apace.

\section{Staff believes that fiscal policy should not provide additional stimulus at this} point in the economic cycle. This would strike an appropriate balance between limiting macroeconomic risks and facilitating the government's desire to accelerate reforms. It does not believe that regional and local governments will cut spending and run a surplus, given the weak framework for controlling spending at lower levels of government. Additional measures yielding 1-1 1/4 percent of GDP should, therefore, be included in the draft 2005 budget to ensure an unchanged fiscal stance. Taxes from oil prices above $\$ 20$ a barrel should continue to be fully saved in the stabilization fund.

\section{Once cyclical pressures ease, there would be a case for spending more on} carefully elaborated long-term reforms, implying a larger deficit at constant oil prices. Given the relatively low public sector debt and good prospects for growth, a small deficit over the full oil price cycle would be sustainable; balancing the budget might be unduly restrictive, considering that important reforms entail significant budgetary costs. On the other hand, if private demand continues to grow strongly, fiscal policy would need to be more restrained and savings in the stabilization fund higher. The challenge will be to maintain a 
fiscal stance that at no point in the oil price cycle will require a pro-cyclical tightening. The appropriate strategy with regard to oil revenues will thus need to be flexible, to allow changes as circumstances warrant. But if harnessed in support of strong reforms, Russia's oil wealth provides the authorities with enviable room for maneuver.

\section{Monetary policy should focus on reducing inflation, unburdened of exchange}

rate considerations. With a continued recovery in money demand, there is scope for some unsterilized interventions while keeping inflation on a downward path, but they should cease or be scaled back and the ruble allowed to appreciate if they threaten the inflation target. Making clear to the market that the CBR will focus on inflation and allow ruble appreciation is likely to increase short-term exchange rate variability and so discourage speculative capital inflows. Unremunerated deposit requirements will only stem capital inflows temporarily, if at all, and are not an alternative to a more flexible exchange rate policy.

\section{The early reduction in inflation to 3 percent called for by President Putin is} desirable and achievable. The disinflationary pressures from the inevitable real ruble appreciation will facilitate this, as will the prospect for continued remonetization. While the CBR's headline inflation target of $7 \frac{1}{2}$ percent by end-2005 could be more ambitious, the more important point is that there should be a corresponding decline in core inflation. Using administered prices to bear down on inflation must be resisted. It merely postpones inevitable price increases, at considerable cost to resource allocation and structural reforms.

\section{Recent turmoil in the banking sector shows the urgency of strengthening crisis} management tools while pressing ahead with closing unsound banks. It points clearly to insufficient vigilance in the past, as well as weaknesses in the resolution and crisis management framework, not to any mistake in the more recent decision to begin closing unsound banks. It would, therefore, be regrettable if the turmoil was to lead to renewed forbearance and reluctance to close banks. This is especially important because the recent decision to extend interim deposit insurance to all banks increases moral hazard, and because the favorable macroeconomic environment could be masking problems that will surface only if oil prices drop. The sudden loss of confidence at a time when the environment is good is thus a sobering reminder of problems that could arise under much less benign circumstances. It is therefore crucial that the CBR remains unwavering in enforcing sound prudential standards as it assesses eligibility for participation in the deposit insurance scheme. Without such resolve, the CBR will in effect have surrendered what it has insisted is the pivotal instrument in its reform strategy. Further delays will only increase the ultimate cost to the government of dealing with the problems. While closing banks clearly involves risks, a more effective crisis management framework, including prompt depositor payout under the deposit insurance scheme, would help to limit contagion. Staff believes that it is preferable that negative repercussions surface now while systemic vulnerabilities are manageable. The CBR will need the full support of the government to improve the soundness of the system.

56. The government's reform agenda is generally well-focused. The priority given to improving the still poor investment climate for small and medium-sized enterprises is important, if the economy is to diversify away from its dependence on oil and a few large conglomerates. The priority given to reform of government is particularly important as the 
public sector's large claim on resources and its still pervasive interference in the economy remain a serious obstacle to investment. Also important is the focus on banking reforms, to increase the still low level of intermediation; on housing reforms, to reduce severe labor market bottlenecks; and on early WTO accession, to promote competition and broader legislative and regulatory reforms.

57. But there is a gap between intentions and achievements. After a burst of reforms in 2000-01, the momentum slowed significantly. Most of the objectives on the government's agenda are not new, but preparations and implementation have been stalled or progressed only slowly for some time owing to fierce resistance from vested interests. The reasons are plain: most of the important achievements to date, such as tax and land reforms, have had broad popular support; most of the key reforms that lie ahead will involve socially difficult changes or resistance from powerful stakeholders. In this regard, it is essential that high oil prices and strong economic growth be viewed not as grounds for complacency but as a unique opportunity to carry out the structural reforms needed to sustain growth over the medium term.

58. It is proposed that the next Article IV consultation for Russia be conducted on the standard 12-month cycle. 
Table 1. Russian Federation: Selected Macroeconomic Indicators

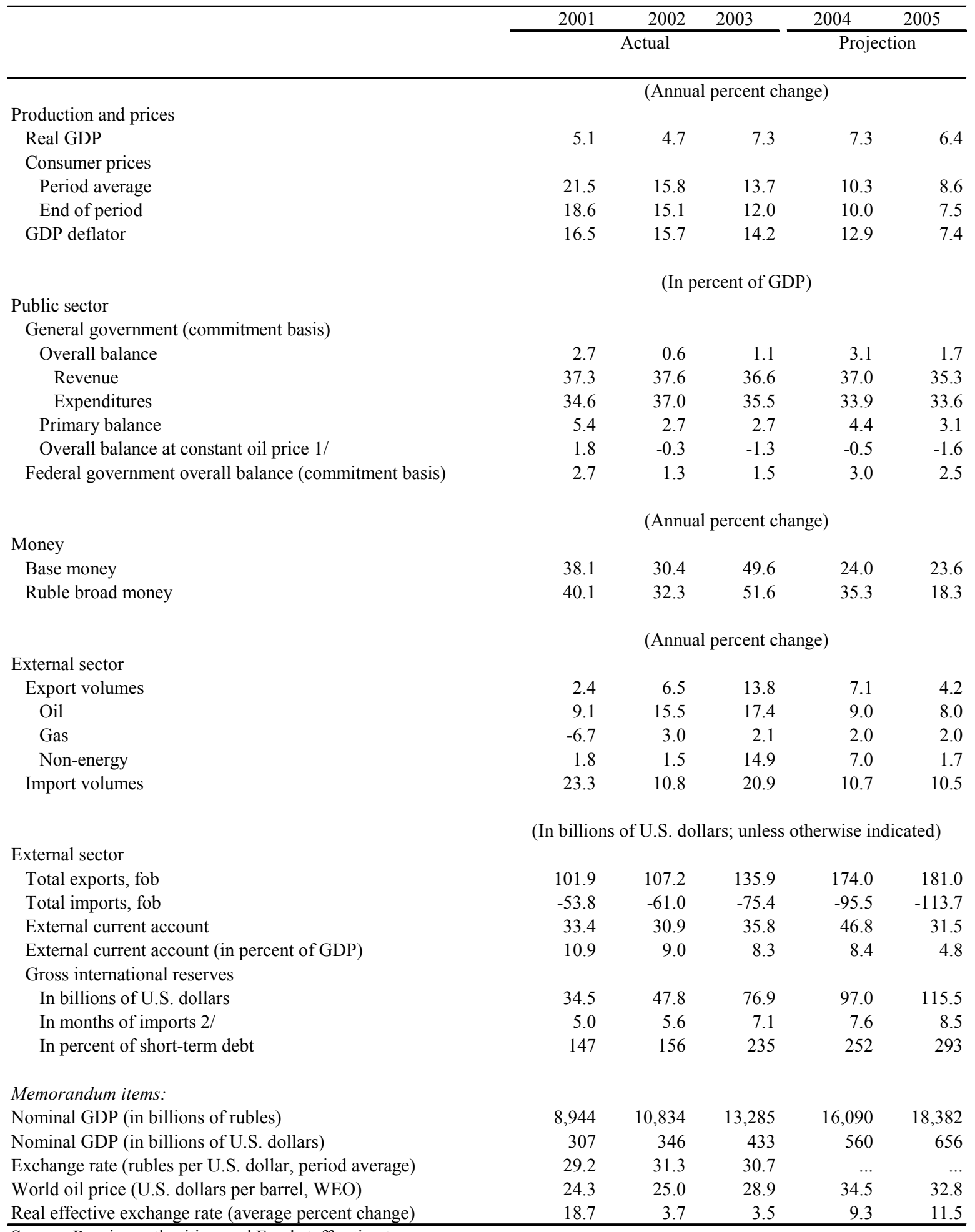

Source: Russian authorities, and Fund staff estimates.

1/ At an oil price of $\$ 20$ per barrel.

2/ In months of imports of goods and non-factor services. 
Table 2. Russian Federation: Macroeconomic Framework

\begin{tabular}{|c|c|c|c|c|c|c|c|c|c|}
\hline & 2001 & 2002 & 2003 & 2004 & 2005 & 2006 & 2007 & 2008 & 2009 \\
\hline & & & Est. & \multicolumn{6}{|c|}{ Projections } \\
\hline & \multicolumn{9}{|c|}{ (In percent of GDP, unless otherwise indicated) } \\
\hline \multicolumn{10}{|l|}{ I. Savings-Investment Balances } \\
\hline \multicolumn{10}{|l|}{ General Government } \\
\hline Gross investment & 3.1 & 3.2 & 2.8 & 3.0 & 3.0 & 3.0 & 3.0 & 3.0 & 3.0 \\
\hline Net income from abroad & -2.1 & -1.6 & -0.8 & -0.6 & -0.5 & -0.3 & -0.3 & -0.2 & -0.2 \\
\hline National savings & 5.8 & 3.8 & 3.9 & 6.1 & 4.7 & 3.9 & 3.5 & 3.3 & 3.1 \\
\hline National savings - investment & 2.7 & 0.6 & 1.1 & 3.1 & 1.7 & 0.9 & 0.5 & 0.3 & 0.1 \\
\hline \multicolumn{10}{|l|}{ Private Sector } \\
\hline Gross investment & 18.9 & 17.0 & 17.8 & 17.8 & 18.9 & 20.0 & 20.6 & 21.0 & 21.5 \\
\hline Net income from abroad & 0.0 & -0.2 & -2.3 & -2.5 & -2.2 & -2.2 & -2.2 & -2.2 & -1.1 \\
\hline National savings & 27.1 & 25.4 & 25.0 & 23.1 & 22.0 & 21.5 & 21.4 & 21.4 & 21.6 \\
\hline National savings - investment & 8.2 & 8.4 & 7.2 & 5.2 & 3.1 & 1.5 & 0.9 & 0.4 & 0.1 \\
\hline \multicolumn{10}{|l|}{ Overall Economy } \\
\hline Gross investment & 21.9 & 20.2 & 20.6 & 20.8 & 21.9 & 23.0 & 23.6 & 24.0 & 24.5 \\
\hline Net income from abroad & -2.0 & -1.8 & -3.1 & -3.1 & -2.7 & -2.5 & -2.5 & -2.5 & -1.3 \\
\hline National savings & 32.9 & 29.1 & 28.9 & 29.2 & 26.7 & 25.4 & 24.9 & 24.7 & 24.7 \\
\hline National savings - investment (current account) & 10.9 & 9.0 & 8.3 & 8.4 & 4.8 & 2.4 & 1.3 & 0.7 & 0.2 \\
\hline \multicolumn{10}{|c|}{ (In percent of GDP) } \\
\hline \multicolumn{10}{|l|}{ II. General government accounts } \\
\hline Revenues & 37.3 & 37.6 & 36.6 & 37.0 & 35.3 & 33.6 & 33.0 & 32.5 & 32.3 \\
\hline Expenditure & 34.6 & 37.0 & 35.5 & 33.9 & 33.6 & 32.7 & 32.6 & 32.2 & 32.3 \\
\hline Noninterest expenditure & 31.9 & 34.9 & 33.8 & 32.6 & 32.2 & 31.8 & 31.8 & 31.6 & 31.7 \\
\hline Overall balance & 2.7 & 0.6 & 1.1 & 3.1 & 1.7 & 0.9 & 0.5 & 0.3 & 0.1 \\
\hline Primary balance & 5.4 & 2.7 & 2.7 & 4.4 & 3.1 & 1.8 & 1.2 & 0.9 & 0.7 \\
\hline \multicolumn{10}{|c|}{ (In billions of U.S. dollars, unless otherwise indicated) } \\
\hline \multicolumn{10}{|l|}{ III. Balance of payments and external debt } \\
\hline External current account & 33.4 & 30.9 & 35.8 & 46.8 & 31.5 & 18.3 & 10.9 & 5.9 & 2.1 \\
\hline Change in external terms of trade (in percent) & -2.6 & -4.1 & 9.5 & 4.4 & -7.3 & -6.5 & -3.6 & -1.8 & -2.5 \\
\hline Change in Russian crude oil price (in percent) & -15.5 & 1.1 & 18.6 & 18.2 & -5.1 & -6.9 & -3.3 & -1.7 & -3.4 \\
\hline Official reserves & 34.5 & 47.8 & 76.9 & 97.0 & 115.5 & 127.6 & 137.0 & 145.8 & 160.1 \\
\hline in months of imports & 5.0 & 5.6 & 7.1 & 7.6 & 8.5 & 8.9 & 9.0 & 8.7 & 8.8 \\
\hline Public external debt service / exports of goods and services (in percent) & 15.1 & 9.3 & 10.0 & 5.8 & 6.6 & 6.0 & 6.1 & 6.9 & 4.5 \\
\hline \multicolumn{10}{|c|}{ (In percent, unless otherwise indicated) } \\
\hline \multicolumn{10}{|l|}{ IV. Growth and prices } \\
\hline Real GDP growth & 5.1 & 4.7 & 7.3 & 7.3 & 6.4 & 5.5 & 5.0 & 5.0 & 5.0 \\
\hline CPI Inflation, end of period & 18.6 & 15.1 & 12.0 & 10.0 & 7.5 & 6.0 & 4.0 & 3.0 & 3.0 \\
\hline CPI Inflation, average & 21.5 & 15.8 & 13.7 & 10.3 & 8.6 & 6.8 & 5.0 & 3.5 & 3.0 \\
\hline Change in GDP deflator, average & 16.5 & 15.7 & 14.2 & 12.9 & 7.4 & 5.1 & 4.3 & 3.6 & 2.9 \\
\hline Nominal GDP (billions of rubles) & 8,944 & 10,834 & 13,285 & 16,090 & 18,382 & 20,384 & 22,325 & 24,286 & 26,241 \\
\hline Nominal GDP (billions of U.S. dollars) & 307 & 346 & 433 & 560 & 656 & 748 & 827 & 899 & 972 \\
\hline Real effective exchange rate, end of period change & 9.8 & 0.2 & 6.5 & 13.4 & 10.2 & 4.9 & 1.6 & 0.7 & 0.6 \\
\hline Real effective exchange rate, average change & 18.7 & 3.7 & 3.5 & 9.3 & 11.5 & 7.4 & 3.2 & 1.1 & 0.6 \\
\hline
\end{tabular}

Source: Staff estimates and projections based on official data. 
Table 3. Russian Federation: Balance of Payments Projections

(In billions of U.S. dollars, unless otherwise indicated)

\begin{tabular}{|c|c|c|c|c|c|c|c|c|c|}
\hline & 2001 & 2002 & 2003 & 2004 & 2005 & 2006 & 2007 & 2008 & 2009 \\
\hline & & & & \multicolumn{6}{|c|}{ Projections } \\
\hline Current Account & 33.4 & 30.9 & 35.8 & 46.8 & 31.5 & 18.3 & 10.9 & 5.9 & 2.1 \\
\hline Trade Balance & 48.1 & 46.3 & 60.5 & 78.4 & 67.4 & 57.8 & 53.8 & 52.4 & 42.4 \\
\hline Exports & 101.9 & 107.2 & 135.9 & 174.0 & 181.0 & 179.6 & 182.5 & 188.6 & 193.4 \\
\hline Non-energy & 50.2 & 51.8 & 62.2 & 79.6 & 83.1 & 82.9 & 84.1 & 86.4 & 88.8 \\
\hline Energy & 51.7 & 55.5 & 73.7 & 94.3 & 98.0 & 96.7 & 98.4 & 102.1 & 104.6 \\
\hline Oil & 34.0 & 39.6 & 53.7 & 70.7 & 72.5 & 72.2 & 74.7 & 78.6 & 81.2 \\
\hline Gas & 17.8 & 15.9 & 20.0 & 23.7 & 25.5 & 24.5 & 23.7 & 23.5 & 23.4 \\
\hline Imports & -53.8 & -61.0 & -75.4 & -95.5 & -113.7 & -121.8 & -128.7 & -136.1 & -151.0 \\
\hline Services (net) & -13.9 & -15.0 & -24.3 & -31.2 & -35.4 & -39.1 & -42.4 & -46.1 & -39.8 \\
\hline Nonfactor services & -8.4 & -9.1 & -11.1 & -14.4 & -18.1 & -20.5 & -22.4 & -24.3 & -27.6 \\
\hline Factor services & -5.5 & -6.0 & -13.2 & -16.8 & -17.3 & -18.5 & -20.0 & -21.8 & -12.3 \\
\hline Public sector interest & -6.6 & -5.6 & -5.2 & -5.1 & -4.9 & -4.6 & -4.5 & -4.4 & -4.0 \\
\hline Other factor services & 1.1 & -0.3 & -7.9 & -11.7 & -12.4 & -13.9 & -15.5 & -17.4 & -8.3 \\
\hline Current transfers & -0.8 & -0.3 & -0.4 & -0.4 & -0.4 & -0.4 & -0.4 & -0.5 & -0.5 \\
\hline Capital and financial account & -13.9 & -10.9 & -0.6 & -17.3 & -3.9 & 2.7 & 6.9 & 11.0 & 20.0 \\
\hline Capital transfers & -0.5 & -0.5 & -1.0 & -1.0 & -1.0 & -1.0 & -1.0 & -1.0 & -1.0 \\
\hline Federal capital & -6.8 & -6.6 & -4.4 & -5.5 & -6.1 & -5.0 & -5.8 & -8.2 & -3.9 \\
\hline Budgetary & -5.2 & -4.9 & -7.4 & -4.5 & -5.1 & -4.0 & -4.8 & -7.2 & -2.9 \\
\hline Disbursements & 0.6 & 0.7 & 0.8 & 0.0 & 2.0 & 2.2 & 2.5 & 2.7 & 2.9 \\
\hline Amortization & -5.8 & -5.5 & -8.2 & -4.5 & -7.1 & -6.3 & -7.3 & -9.9 & -5.8 \\
\hline Non-budgetary & -1.6 & -1.8 & 3.0 & -1.0 & -1.0 & -1.0 & -1.0 & -1.0 & -1.0 \\
\hline Local Governments & -0.2 & -0.5 & -0.2 & 0.0 & 0.0 & 0.0 & 0.0 & 0.0 & 0.0 \\
\hline Private sector capital & -6.4 & -3.3 & 5.0 & -10.8 & 3.2 & 8.7 & 13.8 & 20.2 & 24.9 \\
\hline Direct investment & -0.2 & -1.2 & -3.0 & -1.1 & -0.4 & 0.5 & 2.4 & 4.5 & 6.1 \\
\hline Portfolio investment & 0.6 & 2.0 & -0.8 & -0.8 & -0.9 & -0.9 & -0.9 & -0.9 & -1.0 \\
\hline Commercial banks & 1.0 & 2.2 & 10.3 & 2.0 & 6.0 & 6.5 & 7.0 & 8.5 & 9.1 \\
\hline Corporations & 0.4 & 8.3 & 12.0 & 11.1 & 16.4 & 17.6 & 18.8 & 20.1 & 21.5 \\
\hline Other private capital & -8.2 & -14.7 & -13.4 & -21.9 & -17.9 & -14.9 & -13.5 & -11.9 & -10.9 \\
\hline Errors and omissions, net & -10.2 & -7.5 & -5.2 & -7.8 & -7.8 & -7.8 & -7.8 & -7.8 & -7.8 \\
\hline Overall balance & 9.3 & 12.5 & 30.1 & 21.7 & 19.8 & 13.2 & 10.1 & 9.1 & 14.3 \\
\hline Financing & -9.3 & -12.5 & -30.1 & -21.7 & -19.8 & -13.2 & -10.1 & -9.1 & -14.3 \\
\hline Net international reserves & -10.7 & -13.0 & -31.2 & -21.7 & -19.8 & -13.2 & -10.1 & -9.1 & -14.3 \\
\hline Gross reserves ( - increase) & -8.8 & -9.4 & -29.1 & -20.1 & -18.5 & -12.1 & -9.4 & -8.8 & -14.3 \\
\hline Net Fund liabilities & -3.8 & -1.5 & -2.0 & -1.6 & -1.2 & -1.1 & -0.7 & -0.3 & 0.0 \\
\hline Purchases & 0.0 & 0.0 & 0.0 & 0.0 & 0.0 & 0.0 & 0.0 & 0.0 & 0.0 \\
\hline Repurchases & -3.8 & -1.5 & -2.0 & -1.6 & -1.2 & -1.1 & -0.7 & -0.3 & 0.0 \\
\hline Other liabilities & 1.9 & -2.1 & 0.0 & 0.0 & 0.0 & 0.0 & 0.0 & 0.0 & 0.0 \\
\hline Valuation adjustment & 0.7 & -0.8 & 3.2 & 0.0 & 0.0 & 0.0 & 0.0 & 0.0 & 0.0 \\
\hline Arrears and rescheduling & 0.7 & 1.3 & -2.1 & 0.0 & 0.0 & 0.0 & 0.0 & 0.0 & 0.0 \\
\hline \multicolumn{10}{|l|}{ Memorandum items: } \\
\hline Current account (in percent of GDP) & 10.9 & 9.0 & 8.3 & 8.4 & 4.8 & 2.4 & 1.3 & 0.7 & 0.2 \\
\hline Gross reserves 1 / & 34.5 & 47.8 & 76.9 & 97.0 & 115.5 & 127.6 & 137.0 & 145.8 & 160.1 \\
\hline (in months of imports of GNFS) & 5.0 & 5.6 & 7.1 & 7.6 & 8.5 & 8.9 & 9.0 & 8.7 & 8.8 \\
\hline (as a percent of short-term debt) 2 / & 147 & 156 & 235 & 252 & 293 & 311 & 296 & 325 & $\ldots$ \\
\hline (as a percent of public debt service) & 309 & 315 & 684 & 730 & 963 & 1023 & 940 & 1487 & $\ldots$ \\
\hline Net private capital outflows (in percent of trade) & 10.7 & 6.4 & 0.1 & 6.9 & 1.6 & -0.3 & -1.9 & -3.8 & -5.0 \\
\hline World oil price (\$barrel) (WEO) & 24.3 & 25.0 & 28.9 & 34.5 & 32.8 & 30.5 & 29.5 & 29.0 & 28.0 \\
\hline Terms of trade (percent) & -2.6 & -4.1 & 9.5 & 4.4 & -7.3 & -6.5 & -3.6 & -1.8 & -2.5 \\
\hline \multirow{2}{*}{$\begin{array}{l}\text { Public external debt service payments } 3 / \\
\text { (percent of exports of goods and services) }\end{array}$} & 17.0 & 11.2 & 15.2 & 11.2 & 13.3 & 12.0 & 12.5 & 14.6 & 9.8 \\
\hline & 15.1 & 9.3 & 10.0 & 5.8 & 6.6 & 6.0 & 6.1 & 6.9 & 4.5 \\
\hline Public external debt 4/ & 111.8 & 103.3 & 93.8 & 87.7 & 81.3 & 76.1 & 70.6 & 63.1 & 60.2 \\
\hline (percent of GDP) & 36.5 & 29.9 & 21.6 & 15.7 & 12.4 & 10.2 & 8.5 & 7.0 & 6.2 \\
\hline Private external debt (incl local gov't) & 38.6 & 49.1 & 72.1 & 86.1 & 110.0 & 135.7 & 163.2 & 193.7 & 226.2 \\
\hline Total external debt & 150.4 & 149.7 & 165.9 & 173.8 & 191.3 & 211.9 & 233.9 & 256.8 & 286.4 \\
\hline (percent of GDP) & 49.1 & 43.4 & 38.2 & 31.0 & 29.1 & 28.3 & 28.3 & 28.5 & 29.5 \\
\hline
\end{tabular}

Source: Central Bank of Russia; and Fund staff estimat

1/ Excluding repos with non-residents to avoid double counting of reserves.

2/ Excludes arrears.

3/ Net of rescheduling.

4/ Adjusted for resident MinFin and eurobonds and nonresidents' GKO/OFZs. 


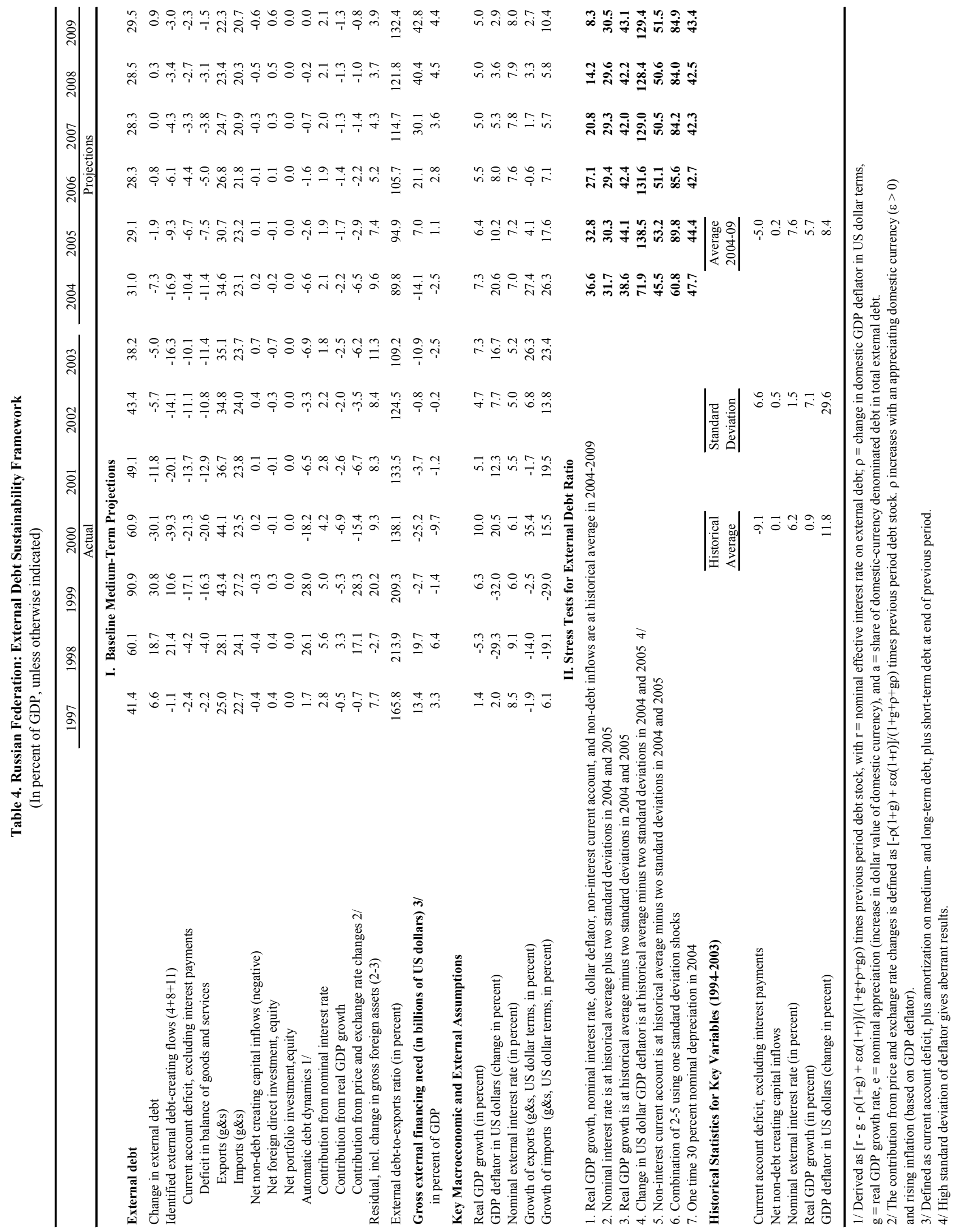


Table 5. Russian Federation: Indicators of External Vulnerability

(In percent of GDP, unless otherwise indicated)

$2001 \quad 2002 \quad 2003 \quad$ Q1 2004

Prel.

\section{Financial indicators}

Public sector debt 1 /

Ruble broad money (percent change, 12-month basis)

Private sector credit (percent change, 12 month basis)

90 day GKOs yield

90 day GKOS yield (real, deflated by actual CPI inflation)

\section{External Indicators}

Exports (percent change in US\$)

Imports (percent change in US\$)

Terms of Trade (percent change, 12-month basis)

Current account balance (billions of US\$)

Capital and financial account balance (billions of US\$)

Gross official reserves (in billions of US\$)

Liabilities to the Fund (in billions of US\$)

Short term foreign assets of the financial sector (in billions of US\$)

Short term foreign liabilities of the financial sector (in billions of US\$)

Official reserves in months of imports GS

Ruble broad money to reserves

Total external debt (in billions of US\$)

$\mathrm{o} / \mathrm{w}$ : Public sector debt (in billions of US\$)

Total external debt to exports GS (in percent)

External interest payments to exports GS

External amortization payments to exports GS

Exchange rate (per US\$, period average)

REER depreciation (-) (12 month basis)

\begin{tabular}{rrrr}
42.4 & 36.2 & 26.8 & \multicolumn{1}{c}{$\ldots$} \\
40.1 & 32.3 & 51.6 & 55.3 \\
56.0 & 36.0 & 46.6 & 48.8 \\
14.7 & 12.7 & 3.3 & 2.6 \\
-3.9 & -2.4 & -8.7 & -6.9
\end{tabular}

$\begin{array}{rrrc}-3.0 & 5.3 & 26.7 & 20.0 \\ 19.8 & 13.4 & 23.7 & 21.3 \\ -2.6 & -4.1 & 9.5 & \ldots \\ 33.4 & 30.9 & 35.8 & 13.0 \\ -13.9 & -10.9 & -0.6 & -2.5 \\ 34.5 & 47.8 & 76.9 & 83.4 \\ 7.4 & 6.5 & 5.1 & 4.6 \\ 12.9 & 13.1 & 13.4 & 17.2 \\ 4.5 & 5.0 & 9.1 & 7.3 \\ 5.0 & 5.6 & 7.1 & \ldots \\ 1.5 & 1.4 & 1.4 & 1.4 \\ 150.4 & 149.7 & 165.9 & \ldots \\ 111.8 & 103.3 & 93.8 & \ldots \\ 133.5 & 124.5 & 112.0 & \ldots \\ 7.7 & 6.3 & 5.1 & \ldots \\ 18.3 & 18.0 & 8.4 & \ldots \\ 29.2 & 31.3 & 30.7 & 28.6 \\ 9.8 & 0.2 & 6.5 & 7.9\end{array}$

\section{Financial Market Indicators}

Stock market index 2/

Foreign currency debt rating 3/

Spread of benchmark bonds (basis points, end of period) 4/
260.1

$\mathrm{B}+/ \mathrm{Stab}$

578.9
359.1

567.3

752.7

B/Stable BB/Stable $\mathrm{BB}+/$ Stable

$376.7 \quad 198.1$

1/ External and domestic debt.

2/ RTS index, end of period.

3/ S\&P long-term foreign currency rating, end of period.

4/ 2007, 10-year Eurobond in US\$, spreads over treasuries, end of period. 
Table 6. Russian Federation: Monetary Accounts

(In billions of rubles, unless otherwise indicated)

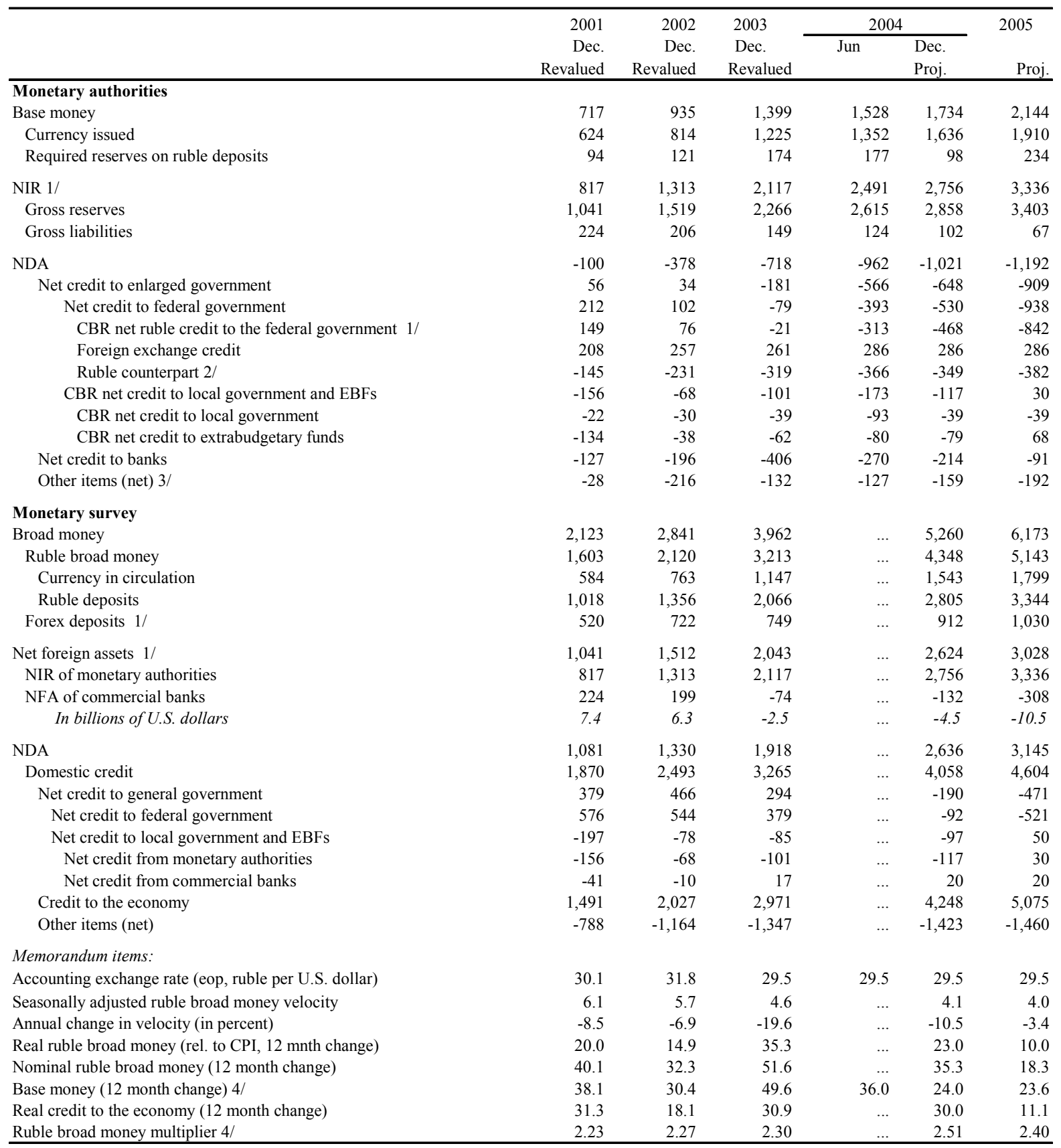

Sources: Russian authorities; and Fund staff estimates.

1/ Data for 2004-2005 calculated at accounting exchange rates of Rub29.5/US\$ and US\$1.486/SDR.

2/ Represents the government's use of NIR resources and calculated in flow ruble terms.

3 / Inclusive of valuation gains and losses on holdings of government securities.

4/ The increase in the multiplier in 2004 includes a reduction in reserve requirements from 7 to 3.5 percent in July 2004 . The reduction is assumed to be reversed in 2005 . 
Table 7. Russian Federation: Fiscal Operations 1/

(in percent of GDP; unless otherwise indicated)

\begin{tabular}{|c|c|c|c|c|c|c|}
\hline & \multirow[t]{2}{*}{2001} & \multirow[t]{2}{*}{2002} & \multirow{2}{*}{$\begin{array}{r}2003 \\
\text { Est. } \\
\end{array}$} & \multicolumn{2}{|c|}{2004} & \multirow{2}{*}{$\begin{array}{l}\mathbf{2 0 0 5} \\
\text { Proj. }\end{array}$} \\
\hline & & & & Budget & Proj. & \\
\hline \multicolumn{7}{|l|}{ General Government } \\
\hline Total revenue & 37.3 & 37.6 & 36.6 & 34.2 & 37.0 & 35.3 \\
\hline Tax revenue & 35.0 & 35.1 & 34.0 & 31.8 & 33.9 & 32.5 \\
\hline Corporate profit tax & 5.8 & 4.3 & 4.0 & 4.4 & 4.2 & 3.8 \\
\hline Personal income tax & 2.9 & 3.3 & 3.4 & 3.5 & 3.3 & 3.3 \\
\hline VAT & 7.2 & 6.9 & 6.6 & 6.5 & 7.1 & 7.0 \\
\hline Excises & 2.7 & 2.4 & 2.6 & 1.6 & 1.7 & 1.6 \\
\hline Customs tariffs & 3.7 & 3.0 & 3.4 & 3.5 & 4.2 & 4.7 \\
\hline Resource extraction tax & 1.4 & 2.1 & 2.6 & 2.1 & 2.6 & 2.4 \\
\hline Social security taxes & 7.3 & 8.0 & 7.8 & 7.5 & 7.5 & 6.3 \\
\hline Other & 4.2 & 5.0 & 3.5 & 2.8 & 3.3 & 3.3 \\
\hline $\mathrm{o} / \mathrm{w}$ : Budgetary funds & 1.8 & 1.2 & 0.9 & 0.0 & 0.8 & 0.8 \\
\hline Nontax revenue & 2.3 & 2.5 & 2.6 & 2.3 & 3.0 & 2.8 \\
\hline Total Expenditure & 34.6 & 37.0 & 35.5 & 33.6 & 33.9 & 33.6 \\
\hline Interest & 2.7 & 2.1 & 1.7 & 1.9 & 1.3 & 1.4 \\
\hline Non-interest & 31.9 & 34.9 & 33.8 & 31.8 & 32.6 & 32.2 \\
\hline \multicolumn{7}{|l|}{ Of which } \\
\hline Education & 3.2 & 3.8 & 3.6 & $\ldots$ & 3.4 & 3.4 \\
\hline Health & 3.2 & 3.7 & 3.6 & $\ldots$ & 3.5 & 3.4 \\
\hline Housing \& communal services & 2.6 & 2.4 & 1.9 & $\ldots$ & 1.8 & 1.8 \\
\hline Other social expenditures & 9.1 & 10.6 & 9.6 & $\ldots$ & 9.3 & 9.2 \\
\hline Primary balance & 5.4 & 2.7 & 2.7 & 2.4 & 4.4 & 3.1 \\
\hline Overall balance & 2.7 & 0.6 & 1.1 & 0.5 & 3.1 & 1.7 \\
\hline Financing & -2.7 & -0.6 & -1.1 & -0.5 & -3.1 & -1.7 \\
\hline Foreign & -2.3 & -1.6 & -1.8 & -0.8 & -0.8 & -0.8 \\
\hline Domestic & -0.4 & 1.0 & 0.7 & 0.3 & -2.3 & -0.9 \\
\hline Monetary Authority & -0.9 & -0.6 & -1.2 & $\ldots$ & -2.7 & -3.0 \\
\hline Commerical Banks & 0.1 & 1.0 & 0.4 & $\ldots$ & -0.1 & -0.1 \\
\hline Other & 0.3 & 0.6 & 1.4 & $\ldots$ & 0.5 & 2.2 \\
\hline Arrears/Rescheduling & 0.1 & 0.0 & 0.0 & 0.0 & 0.0 & 0.0 \\
\hline \multicolumn{7}{|l|}{ Memorandum items: } \\
\hline Non-oil primary balance & -2.3 & -4.7 & -5.2 & $\ldots$ & -4.0 & -5.4 \\
\hline Non-oil overall balance & -5.0 & -6.8 & -6.9 & $\ldots$ & -5.3 & -6.7 \\
\hline \multicolumn{7}{|l|}{ Federal Government } \\
\hline Revenue & 17.8 & 17.2 & 16.7 & 14.8 & 16.8 & 16.9 \\
\hline VAT & 7.1 & 6.9 & 6.6 & 6.5 & 7.1 & 7.0 \\
\hline Excises & 2.3 & 2.0 & 1.9 & 0.6 & 0.9 & 0.8 \\
\hline Profit tax & 2.4 & 1.6 & 1.3 & 1.1 & 1.2 & 1.1 \\
\hline Trade taxes & 3.7 & 3.0 & 3.4 & 3.5 & 4.2 & 4.7 \\
\hline Other & 2.2 & 3.7 & 3.4 & 3.1 & 3.5 & 3.4 \\
\hline Expenditure & 15.1 & 15.9 & 15.1 & 14.2 & 13.8 & 14.5 \\
\hline Interest & 2.7 & 2.1 & 1.7 & 1.9 & 1.3 & 1.4 \\
\hline Noninterest & 12.4 & 13.8 & 13.4 & 12.4 & 12.5 & 13.1 \\
\hline \multicolumn{7}{|l|}{ Of which } \\
\hline Wages & 2.6 & 2.6 & 2.6 & $\ldots$ & 2.6 & 2.6 \\
\hline Primary balance & 5.4 & 3.4 & 3.2 & 2.4 & 4.3 & 3.9 \\
\hline Overall balance & 2.7 & 1.3 & 1.5 & 0.5 & 3.0 & 2.5 \\
\hline \multicolumn{7}{|l|}{ Memorandum items: } \\
\hline GDP (billions of rubles) & 8,944 & 10,834 & 13,285 & 15,300 & 16,090 & 18,382 \\
\hline World oil price (\$ / barrel) & 24.3 & 25.0 & 28.9 & $\ldots$ & 34.5 & 32.8 \\
\hline Russian oil price (\$ / barrel, cif) & 22.9 & 23.6 & 27.3 & 22.0 & 30.1 & 28.6 \\
\hline Oil revenue & 5.7 & 5.6 & 6.0 & $\ldots$ & 6.3 & 6.4 \\
\hline Non-oil revenue & 12.1 & 11.5 & 10.7 & $\ldots$ & 10.5 & 10.5 \\
\hline Non-oil primary balance & -0.3 & -2.2 & -2.8 & $\ldots$ & -2.0 & -2.5 \\
\hline Non-oil overall balance & -3.0 & -4.3 & -4.5 & $\ldots$ & -3.3 & -3.9 \\
\hline
\end{tabular}

Sources: Russian authorities, and Fund staff estimates.

1/ Presented on a commitment basis, unless otherwise indicated. 


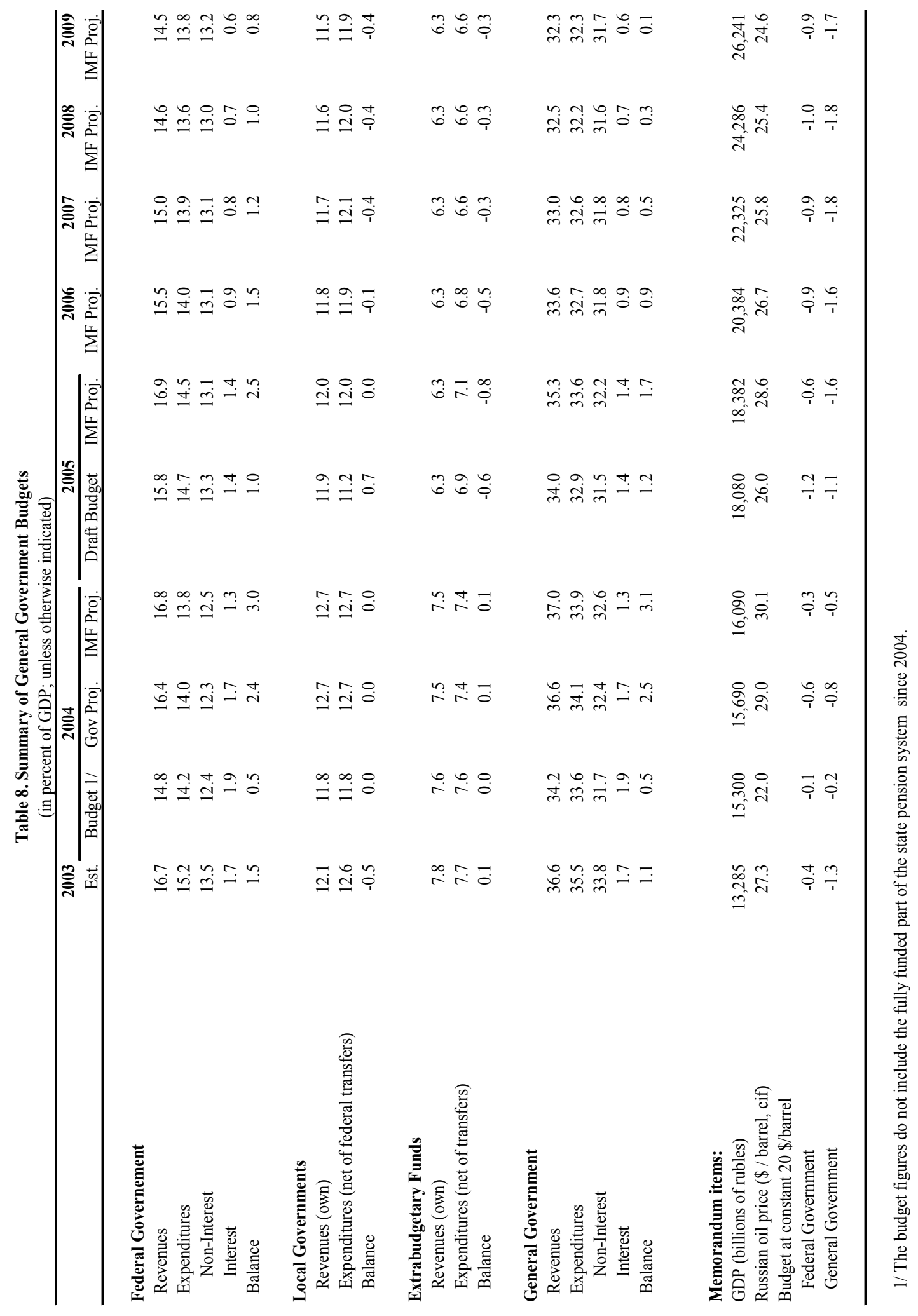




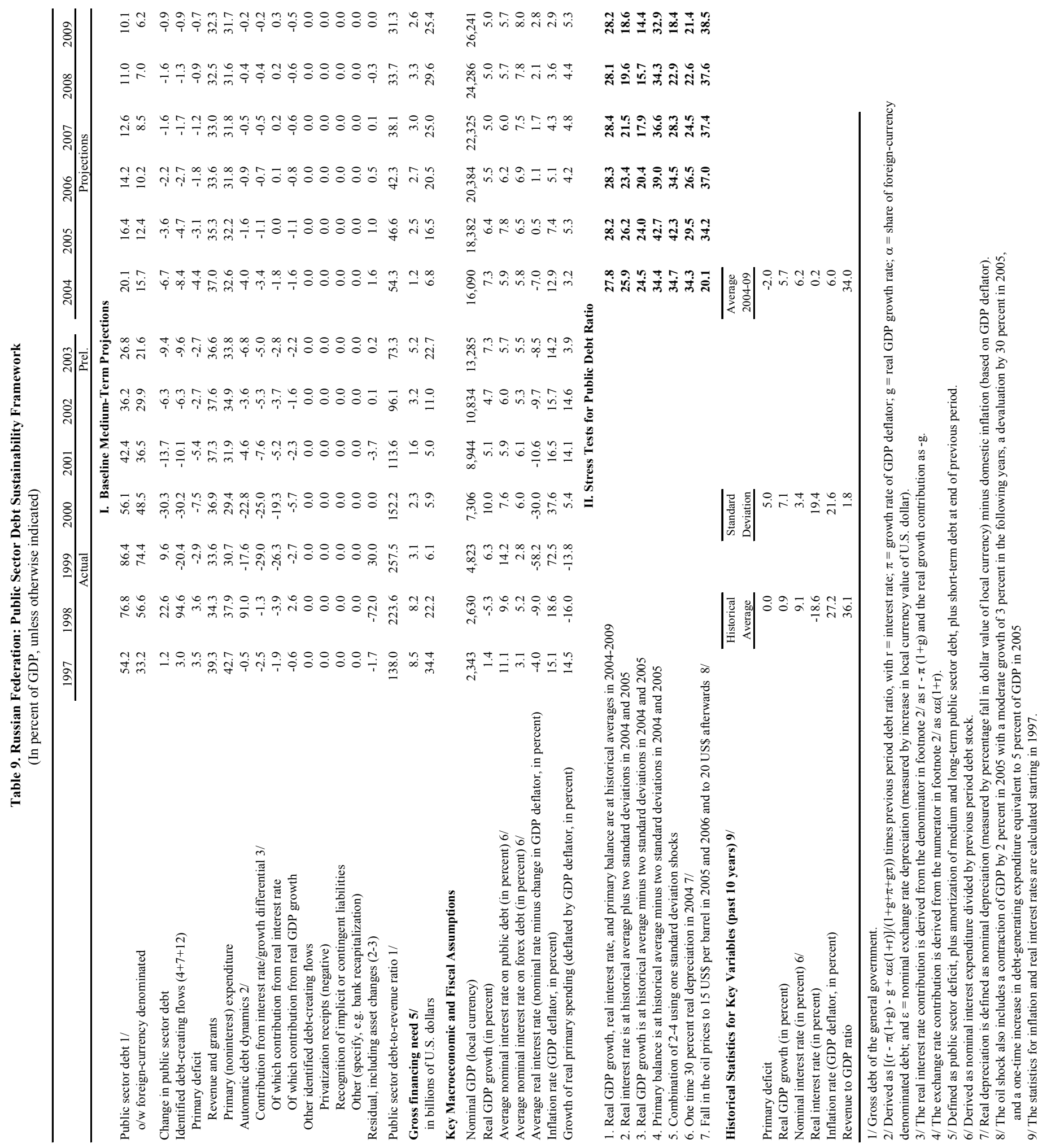




\section{RUSSIAN FEDERATION: FUND RELATIONS}

As of June 30, 2004

I. Membership Status: Joined 06/01/1992; Article VIII.

II. General Resources Account:

Quota

Fund holdings of currency

Reserve Tranche position

III. SDR Department:

Holdings

IV. Outstanding Purchases and Loans:

Stand-By Arrangements

Extended Arrangements
SDR Million

$5,945.40$

$8,721.82$

1.71

SDR Million

0.32

SDR Million

58.93

$2,719.16$
Percent of Quota

100.00

146.70

0.03

Percent of Allocation

n.a.

Percent of Quota

0.99

45.74

V. Latest Financial Arrangements:

\begin{tabular}{lcccc}
\hline \multicolumn{1}{c}{ Type } & $\begin{array}{c}\text { Approval } \\
\text { Date }\end{array}$ & $\begin{array}{c}\text { Expiration } \\
\text { Date }\end{array}$ & $\begin{array}{c}\text { Amount Approved } \\
\text { (SDR million) }\end{array}$ & $\begin{array}{c}\text { Amount Drawn } \\
\text { (SDR million) }\end{array}$ \\
\hline Stand-by & $07 / 28 / 1999$ & $12 / 27 / 2000$ & $3,300.00$ & 471.43 \\
EFF & $03 / 26 / 1996$ & $03 / 26 / 1999$ & $13,206.57$ & $5,779.71$ \\
of which: SRF & $07 / 20 / 1998$ & $03 / 26 / 1999$ & $3,992.47$ & 675.02 \\
Stand-by & $04 / 11 / 1995$ & $03 / 26 / 1996$ & $4,313.10$ & $4,313.10$ \\
\hline
\end{tabular}

VI. Projected Obligations to Fund (SDR million; based on existing use of resources and present holdings of SDRs):

\begin{tabular}{lrrrrr}
\hline & \multicolumn{5}{c}{ Forthcoming } \\
\cline { 2 - 6 } & 2004 & 2005 & 2006 & 2007 & 2008 \\
\hline Principal & 484.32 & 850.78 & 772.91 & 458.68 & 211.40 \\
Charges/Interest & 38.17 & 57.87 & 33.35 & 13.63 & 2.95 \\
Total & 522.49 & 908.65 & 806.26 & 472.30 & 214.36 \\
\hline
\end{tabular}

VII. Exchange Arrangements: Managed float. The exchange rate of the ruble is determined in the interbank foreign exchange market, which was unified on June 29, 1999. The interbank market electronically links exchanges across the country. The official rate of the ruble is set equal to the previous day's weighted average rate in the interbank market. 
The Russian Federation accepted the obligations of Article VIII, Sections 2, 3, and 4 of the IMF Articles of Agreement with effect from June 1, 1996. At the time of the last Article IV consultation on May 2, 2003, the Russian authorities still imposed a number of exchange restrictions that are subject to approval under Article VIII, Sections 2 and 3, and that were not approved by the Executive Board.

The following exchange restrictions subject to Article VIII were identified at the time of the 2003 consultation:

- Conversion Operations through non-residents' $\mathbf{S}$ accounts (exchange restriction and multiple currency practice). These are special accounts for nonresidents used for GKO-OFZ-related transactions. Before balances arising from such transactions can be repatriated, fund have to be transferred to a noninterest bearing transit account for a fixed period. As a result, the repatriation of interest earnings and other current proceeds from $\mathrm{GKO} / \mathrm{OFZ}$ investments would be made with delay and at unfavorable terms.

- Repatriation restrictions on ruble balances of nonresidents not participating in the GKO/OFZ novation (exchange restriction and multiple currency practice). The rules governing the repatriation of ruble balances are similar to those described above with respect to the S-accounts. They apply to ruble balances arising from GKO/OFZ investments which matured before December 31, 1998.

- Restrictions on advance import payments (exchange restriction). The authorities do not freely permit the making of all advance payments that are required under valid import contracts.

- Restrictions on nonresidents' $\mathbf{N}$-accounts (exchange restriction). These are nonresident bank accounts used for trade and some bond-related transactions. Existing restrictions limit the ability of nonresidents to effect moderate amounts of amortization from the proceeds of bond transactions.

- Use of a more depreciated exchange rate for repatriation of S-account balances (exchange restriction and multiple currency practices). Non-residents who participated in the GKO/OFZ novation are allowed to repatriate part of the proceeds by purchasing foreign currency in special auctions arranged by the CBR at a depreciated exchange rate.

The authorities have recently enacted a new Federal Law on Foreign Exchange Regulation and Foreign Exchange Control and are currently drafting the implementing regulations. A comprehensive review of the new legal framework will be required at the end of the legislative overhaul. Staff is working on assessing the jurisdictional implications of various regulations recently enacted by 
the authorities on the existence of the previously identified exchange restrictions and multiple currency practices.

VIII. Article IV Consultation: Russia is on the standard 12-month consultation cycle. The last consultation was concluded on May 2, 2003.

\section{FSAP Participation and ROSCs}

Russia participated in the Financial Sector Assessment Program during 2002, and the FSSA report was discussed by the Board in May 2003, at the time of the 2003 Article IV discussion (IMF Country Report No. 03/147). An MFD TA mission on key monetary, banking, and related issues took place in April 2004. In addition, a long-term advisor on banking supervision will be in Moscow until end-2004.

A Fiscal Transparency ROSC mission, headed by Peter Heller (FAD), visited Moscow in July 2003, and a new Data ROSC module was undertaken by a mission in October 2003, led by Armida San Jose (STA).

\section{Resident Representatives:}

Mr. Poul M. Thomsen, Senior Resident Representative, since January 20, 2001. Mr. Goohoon Kwon, Resident Representative, since September 14, 2001. 


\section{RUSSIAN FEDERATION: RELATIONS WITH THE WORLD BANK GROUP}

1. The current Country Assistance Strategy (CAS) was approved by the Bank's Board in June 2002. Overall, the strategy envisages continued emphasis on Bank support to deepen structural reforms. In particular, the current CAS emphasizes the need to (1) improve the business environment in order to encourage new firm growth, (2) strengthen public sector management (including civil service reform, intergovernmental finance reform and support of judicial reforms), and (3) safeguard against the social and environmental risks of transition. The World Bank Group's work in each of these three areas is described in more detail below.

\section{Improving the business environment and enhancing competition}

- Removing administrative barriers to business activity, including monitoring administrative barriers to small business development and WTO accession advisory work.

- Restructuring priority sectors: preparation underway for lending operations in areas such as the land cadastre and housing and communal services; and advisory work in areas such as electricity and gas sector restructuring, railways restructuring, and urban transport.

- Enhancing the protection of property rights, contract enforcement, and corporate governance, including enterprise support: preparation of a judicial reform project; and IFC and IBRD work on corporate governance.

- Improving financial intermediation: IFC investments and MIGA program; preparation underway for an IBRD regional banks loan to focus on medium-size enterprises; FSAP; advisory work on bank supervision, deposit insurance, and housing finance.

- Strengthening Russia's role in the global knowledge economy: advisory work focusing on science and technology policy; Global Knowledge Economy strategy for Russia; reform of the telecommunication sector; and preparation of a science and technology lending project.

\section{Strengthening public sector management}

- Strengthening and modernizing civil service, public administration and judicial systems: multi-year advisory work, in partnership with DFID and other donors, focusing on civil service reform; and preparation of a judicial reform project.

- Improving public finance: Regional Fiscal Federalism, Treasury Modernization, Tax Administration and Customs Modernization, and St. Petersburg Economic Development IBRD loans; WBI work on intergovernmental fiscal relations and urban and city management capacity building; public expenditure reviews; advisory work on housing and communal service reform; Country Financial Accountability Assessment (CFAA); IDF grant on public expenditure management for the Ministry of Finance. 


\section{Mitigating social and environmental risks}

- Improving health status, services and finance: TB/AIDS and Health Reform Implementation loans; advisory services and capacity building in health policy, adult health, and health insurance.

- Improving relevance and delivery of modern educational services: Education Reform and E-Learning loans; and advisory work on modernizing the education system.

- Mitigating income insecurity, vulnerability and minimizing the risk of poverty: Northern Restructuring loan and preparation of a child welfare project; multi-year capacity building program, in partnership with DFID, aimed at poverty monitoring and policy development; and advisory work on pension reform, child welfare and targeting of social assistance.

- Mitigating environmental risks and improving the environment: Forestry loan and related advisory services; preparation of loan to modernize meteorological forecasting; Global Environment Facility (GEF) program; and advisory work on Environmental Management Systems.

2. The Bank's analytical program encompasses a robust program of just-in-time demand driven policy notes, multi-year technical assistance aimed at building capacity, and deeper analytical studies. The Bank has also adopted a Programmatic Country Economic Memorandum (CEM) approach, which addresses a different theme every year in line with CAS priority areas, rather than aiming at a single report that covers the economy comprehensively. The draft of the first CEM, which assesses the extent of structural change in the Russian Federation and its contribution to long-term growth, has recently been issued. ${ }^{9}$ In this CEM, five connected dimensions of structural change are analyzed:

- Spatial reallocation caused by the legacy of industrialization and urbanization under central planning;

- Reallocation of employment across the economy's main sectors;

- Productivity changes originating from shifts of employment across sectors and from restructuring within sectors;

- Restructuring in the industrial sector; and

- Concentration of ownership and its implication for industrial restructuring and economic performance.

3. The recently completed Poverty assessment develops comparable survey data to estimate trends in poverty and inequality in the Russian Federation. The report documents the success in reducing poverty since 1999 and highlights the challenges facing the country in reducing poverty by half by 2007 . The report stresses the need for a three-pronged strategy:

\footnotetext{
${ }^{9}$ Available via the internet at: http://www.worldbank.org.ru/ECA/Russia.nsf
} 
a. promoting broad-based and diversified growth to reduce poverty;

b. targeting interventions to fight the deep pockets of poverty among children, rural areas and depressed regions; and

c. improving the targeting effectiveness of social programs.

\section{Government priorities and future World Bank Group operations}

4. In his recent public appearances, President Putin has signaled the intention to shift the focus from macroeconomic stability and growth to sustaining high levels of growth and reducing poverty and regional disparity. In light of the growing urgency of the reform agenda covered in the CAS, the government has recently reaffirmed a keen interest in continuing a strategic partnership with the World Bank Group, to encompass policy advice and technical assistance, sovereign lending, joint public and private financing, and guarantees.

5. In light of recent budget surpluses and growing reserves, which have led to the need to strictly limit foreign borrowing for non-interest budget expenditures, the government is seeking to selectively use the IBRD's project design, preparation and monitoring capacity while limiting loan amounts and maintaining flexibility.

6. In order to maximize knowledge transfer associated with loans design and implementation, the IBRD and the government jointly agreed to future sovereign borrowing in three areas:

- $\quad$ public infrastructure projects of national importance;

- institutional strengthening of public administration; and

- social infrastructure.

7. The priority considerations for the future lending program are to increase the amount of government co-financing and to develop new lending instruments and mechanisms, which will allow for tailoring resource flows to the budgetary situation over an extended period of time. 


\section{RUSSIAN FEDERATION: STATISTICAL ISSUES}

1. Russia has a reasonably comprehensive and timely statistical database, but difficulties remain in terms of the data accuracy. State and private enterprise activities are measured through forms sent to firms included in enterprise registers, with sample surveys increasingly replacing full-count collections. The authorities are generally cooperative in reporting data to the Fund, mainly through the resident representative office, and during missions. Data are provided on a timely basis, albeit with a few exceptions. Russia produces a wide range of regular, timely publications on financial and economic statistics. The authorities report data for the Fund's International Financial Statistics (IFS), Government Finance Statistics Yearbook, the Direction of Trade Statistics, and the Balance of Payments Statistics Yearbook.

2. A draft ROSC module on data dissemination practices was prepared in 1999-2000, but never published. A new ROSC data module was prepared in October 2003, and on April 25, 2004, the authorities approved the publication of the report on the IMF website.

3. Recent improvements in data dissemination practices have moved Russia closer to subscription to the SDDS (see below). The Ministry of Finance contacted STA on April 28, 2004 to reiterate Russia's commitment to subscribe to the SDDS. Russia has not yet nominated a National SDDS Coordinator and STA is awaiting an official letter from the authorities in this regard.

\section{National accounts}

4. The State Statistics Committee (Goskomstat) compiles and publishes quarterly and annual national accounts data on a timely basis, using the 1993 System of National Accounts. Source data are obtained from surveys of businesses and households, including financial surveys of businesses and employment surveys of households, and are supplemented by administrative data. There has been much effort to improve coverage, but further progress is needed in covering small and medium enterprises. The estimates of gross domestic product (GDP) are compiled by type of economic activity and expenditure category; however, the estimates by type of activity are considered more accurate. The statistical discrepancy between the production and expenditure approaches is generally no more than 2 percent, which is acceptable by international standards. The data are also presented by income category. Estimates of the financial account by institutional sector are not compiled although these estimates are needed.

5. The delay in finalizing a modern statistics law_-requiring firms to provide data and with realistic penalties for noncompliance, together with a guarantee of confidentiality — is an impediment to further improvement of national accounts data.

6. The authorities do not publish separate data on export and import volumes. Revisions to the data are not flagged when the data are disseminated. As a result, it is difficult for users, including the Fund, to maintain any form of consistent time series. 


\section{Prices}

8. Goskomstat compiles a good quality national consumer price index (CPI), developed with Fund technical assistance. Since January 2003, as a result of achieving moderate inflation in the recent years, Goskomstat has stopped the weekly publication of headline inflation and continued only with monthly reports; in addition, Goskomstat has started the publication of monthly core inflation data. Further improvements could be made on the basis of a new household budget survey - which has been under consideration for some time - and by the current efforts to improve the treatment of seasonal items in the index. World Bank and TACIS assistance is available in these areas. Goskomstat also publishes a producer price index. The State Customs Committee has initiated the development of foreign trade price indexes.

9. Since November 2003, the monthly CPI and PPI are presented in two formats: (i) as an index using annual average prices for 1995 as the reference $(1995=100)$ and (ii) as a percentage of a previous month (the previous month and the same month in the previous year). However, data on the basic components of the CPI and PPI are not readily available in time series format, and the weights of the CPI and PPI components are not disclosed, rendering time series analysis difficult.

\section{Government finance statistics data}

10. The staff is provided with monthly information on revenues, expenditures, and financing of the federal and local governments and quarterly information on revenues, expenditures, and financing of extrabudgetary funds. The published functional classification of expenditure differs slightly from international standards. Expenditure data, classified by economic type, need improvement. Presently, they are compiled with a long delay on an annual basis, with a publication lag of one year. Data on domestic and external federal debt are compiled monthly, but are made public only in summary form on an annual basis; in addition, there is no unified debt monitoring and reporting system. In the context of a work program for statistical improvement agreed with STA, there have been ongoing improvements in the coverage and quality of GFS data, although expenditure data remain poor. The reform of budgetary accounting is well advanced. Its objectives include the introduction of accrual accounting for the whole of government. The latest data provided for publication in the GFS Yearbook for 2002 were reported on an accrual basis, in accordance with the methodology of the Manual on Government Finance Statistics 2001. The Treasury has been reporting aggregate government finance data for publication in IFS on a cash basis since April 1996.

\section{Monetary statistics}

11. Monetary data are reasonably comprehensive and generally in accordance with international standards. The data ROSC mission in 2003 identified the following methodological issues: (1) the scope of monetary statistics did not include financial institutions issuing deposit substitutes, such as mutual funds and financial companies, and 
credit institutions in the process of liquidation; (2) classification and sectorization were in line with the methodological guidelines, except that securities repurchase operations of credit institutions with nonresidents (currently at insignificant levels) were not treated as collateralized loans, and financial derivatives (which are at an initial stage of development in Russia) were not included in the instrument classification; and (3) the basis of recording broadly followed methodological recommendations, except that monetary gold and securities for investment purposes were not valued at current market prices. In addition, accrued interest was not included in the underlying instrument. Following the data ROSC, the authorities included all unoperational credit institutions in the coverage of the monetary statistics and reclassified their deposits as restricted deposits. The Central Bank of Russia (CBR) intends to revise further its compilation procedures to conform fully with the guidelines of the Monetary and Financial Statistics Manual 2000.

12. Analytical accounts for the monetary authorities and commercial banks are reported for publication in IFS with a lag of one month. Timely interest rate data are available.

\section{External sector statistics}

13. The balance of payments is compiled on the basis of the Fund's Balance of Payments Manual (Fifth Edition). In cooperation with the Fund, significant progress has been made with regard to balance of payments statistics. More detailed data have been published and new data sources have been developed. Though significant improvements have been made to enhance the quality of balance of payments statistics, there is further scope to improve the coverage of certain components of the current and the capital and financial account. There is especially also scope to improve the detail of data available to the public especially on the financial account to analyze the relatively complex flows.

14. The State Customs Committee needs to substantially improve the coverage and valuation of exports and imports. Merchandise imports data published by the State Customs Service are subject to large adjustments for under recording, especially for "shuttle trade" by individuals, smuggling, and under-valuation. Large, persistent differences between partner country and customs data on imports remain, although statistical agencies are seeking to reconcile the data with those of partner countries. The CBR has developed a methodology for calculating components of export and import transactions unrecorded by the customs authorities. Goskomstat needs to improve the coverage and quality of surveys on direct investment, and trade in services including travel. The CBR has moved toward direct data collection to address these limitations.

15. Russia has began disseminating the data template on international reserves and foreign currency liquidity. However, published historic series on reserves have not been corrected for changes in definitions. Headline data on reserves are reported to the Fund and the markets on a weekly basis with a four-business day lag. The Fund receives additional detail on reserves and reserve liabilities through the central bank balance sheet, but this is not as comprehensive as the reserve template. 
16. Quarterly external debt data are now published by sector, maturity, instrument, and currency, with a lag of one quarter as prescribed by the SDDS. Moreover, while improvements have been made, there are a number of gaps in data, notably the lack of a debt service schedule. Underlying balance of payments data also lack information on gross payments, for example, for the banking system, which is necessary to monitor liquidity risk. There is also a need to monitor corporate sector off-balance sheet obligations and more generally, information on interest and exchange rate exposure of the sector.

17. The CBR has commenced publishing an annual international investment position for all sectors with data starting in 2001. The international investment position for the banking sector is now available on a quarterly basis.

\section{Special Data Dissemination Standard}

18. Significant progress has been made towards meeting SDDS dissemination requirements. Goskomstat, the MOF, and the CBR are already following the SDDS metadata framework to disseminate information regarding their statistical practices, and Russia's data dissemination practices currently meet most of the SDDS requirements. During the ROSC mission, the authorities disseminated, for the first time, international reserves data using the Fund's Data Template on International Reserves and Foreign Currency Liquidity. After the ROSC mission, Goskomstat published the price statistics in index format $(1995=100)$ on its website, and the CBR disseminated the analytical accounts of the monetary authorities with the timeliness prescribed by the SDDS, beginning with data for the reference period of October 2003. 


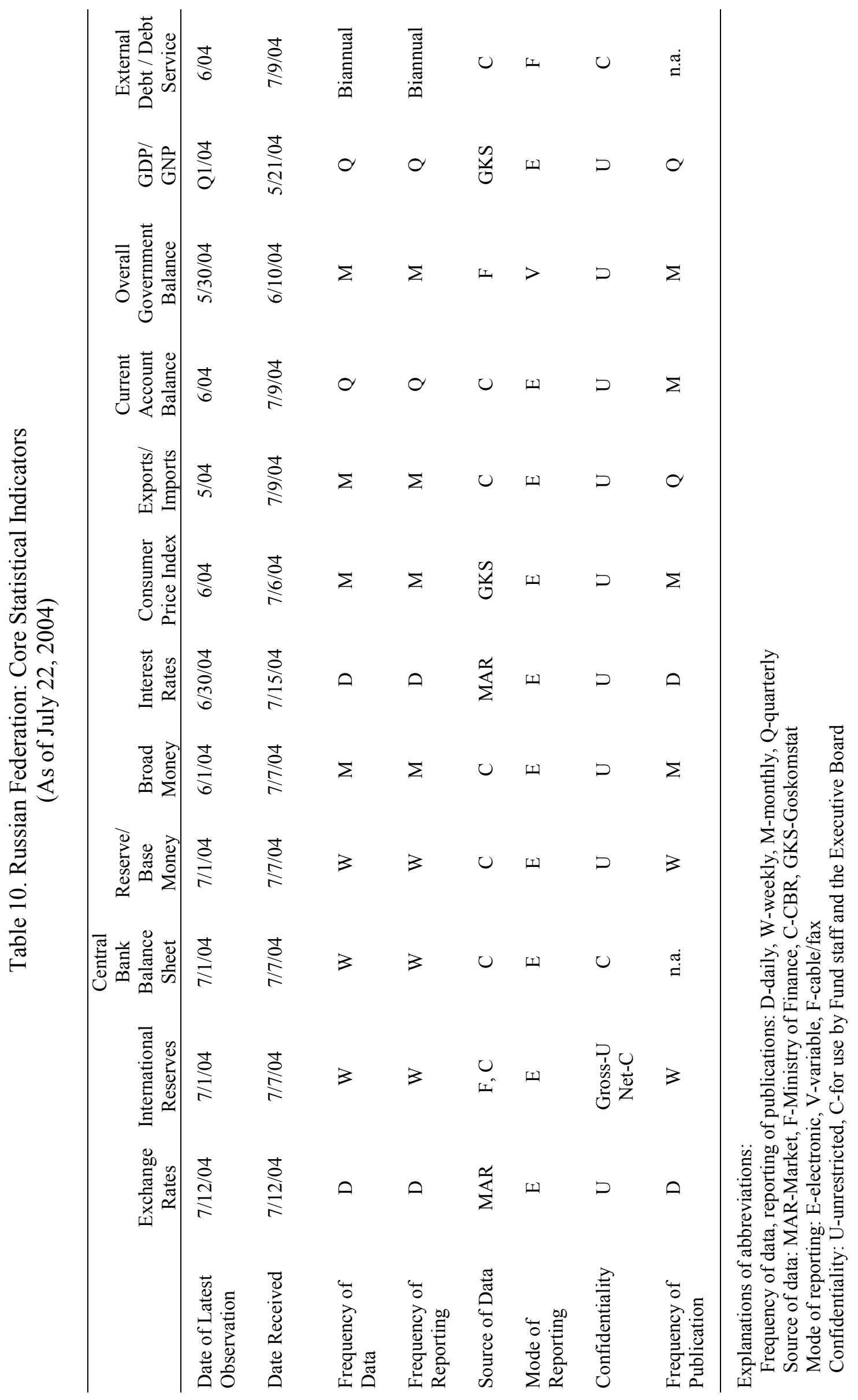




\title{
INTERNATIONAL MONETARY FUND
}

\section{RUSSIAN FEDERATION \\ Staff Report for the 2004 Article IV Consultation Supplementary Information}

\author{
Prepared by European Department
}

Approved by Michael Deppler and Carlos Muñiz

August 30, 2004

1. This supplement contains information on recent economic developments in Russia that has become available since the circulation of the staff report for the Article IV consultation.

\section{The recent rise in oil prices and attendant changes to the WEO oil price} projections - to $\$ 37$ a barrel in 2004 and 2005-have strengthened the balance of payment and fiscal outlook, but are otherwise expected to have only limited macroeconomic implications:

- $\quad$ As to the balance of payments, the current account surplus in 2004 is likely to be higher than previously expected, by perhaps $1 \frac{1}{2}$ percent of GDP, but higher private capital outflows over the summer, as a result of recent turmoil in the banking system and uncertainties arising from the legal proceedings against Yukos, suggest that the overall balance of payments position will not be notably affected this year. Looking to next year and beyond, higher current account surpluses (by 2-3 percent of GDP a year) are expected to translate into an accelerated increase in foreign reserves provided the authorities move forcefully to strengthen the banking system and prove even-handed and transparent in enforcing tax legislation and the rule of law more generally, as discussed in the staff report.

- $\quad$ As to the public sector, higher oil revenues will be fully saved in the oil stabilization fund in 2004. Reflecting mainly higher oil prices, but also payment of back-taxes by Yukos, the draft 2005 budget submitted to the Duma on August 26 assumes that revenues will be about $2 / 3$ percentage points of GDP higher than projected at the time of the mission. Half of these additional revenues have been reflected in higher spending, and the 2005 budget deficit on a constant oil price basis will, therefore, be about $1 / 3$ percent of GDP higher than previously projected, raising the total fiscal stimulus to $1 \frac{1}{3}-1 \frac{1}{2}$ percent of GDP next year. While savings in the oil stabilization fund are supposed to cease once the cap of Rub 500 billion is reached - which under the revised oil price assumption could happen late this year-statements made by the president and the minister of finance at the time of the budget submission suggest that 
any revenues arising from Urals oil prices above the revised budgetary assumption of \$28 per barrel will be saved.

- $\quad$ Recent developments do not suggest any need to change the projections for GDP and inflation in 2004. A recent upward revision by the authorities of their GDP forecast for 2004 has brought this forecast closer to the staff's. As to 2005, while oil export earnings have been revised up by $1 \frac{1}{2}$ percent of GDP, staff has raised its forecast for GDP growth by only $1 / 4$ percentage point, reflecting the likelihood that much of the windfall will be saved, especially as about 80 percent of higher oil sector earnings are taxed at the current level of oil prices. Headline inflation rose slightly in July, to 10.4 percent, and the ruble remained broadly stable against the dollar. The authorities have narrowed the target range for end-year inflation in 2005 to its upper half, from $6 \frac{1}{2}-81 / 2$ percent to $7 \frac{1}{2}-8 \frac{1}{2}$ percent.

3. Regarding other developments, the situation in the banking sector remained calm during August. Amendments to strengthen the bank bankruptcy law, which were approved by the Duma at end-July and by the Federation Council on August 8, were signed into law by the president on August 20. Banks' balance sheet data for July, needed for a fuller assessment of recent developments, are not yet available.

4. Finance Minister Kudrin indicated last week that Russia would like to replace its Paris Club debts with marketable securities. This issue is likely to be discussed by Paris Club creditors once the Russian authorities have made specific proposals. Staff will be in a position to provide a more detailed assessment once the specifics are known.

5. The additional information available since the circulation of the staff report does not alter the general thrust of the staff appraisal. Staff continues to believe that there should be no fiscal stimulus at this point in the economic cycle, whereas the draft 2005 budget submitted to the Duma entails a somewhat larger fiscal stimulus than projected at the time of the mission. More importantly, with oil prices now well above the assumption underlying the 2005 budget, staff views a policy of fully saving oil revenues over and above what is assumed in the budget as key to the authorities' ability to manage the macroeconomic challenges associated with very high oil prices. 


\section{INTERNATIONAL MONETARY FUND}

EXTERNAL

Public Information Notice

RELATIONS

DEPARTMENT

Public Information Notice (PIN) No. 04/112

EMBARGOED

NOT FOR NEWSWIRE TRANSMISSION

International Monetary Fund

$70019^{\text {th }}$ Street, NW

UNTIL 7:30 PM WASHINGTON TIME (2330GMT)

Washington, D. C. 20431 USA

September 30, 2004

\section{IMF Concludes 2004 Article IV Consultation with the Russian Federation}

On September 1, 2004, the Executive Board of the International Monetary Fund (IMF)

concluded the Article IV consultation with the Russian Federation. ${ }^{1}$

\section{Background}

The macroeconomic environment continues to be favorable, with strong GDP growth, moderate inflation and large current account and fiscal surpluses. The oil-driven boom is, however, leading to growing macroeconomic tensions. While the near-term outlook is strong, based on current projections for oil prices, and external vulnerabilities are generally low, recent nervousness in the banking sector and uncertainty related to the Yukos affair highlight the fragility of confidence.

GDP growth rose to 7-71/2 percent in 2003 and the first half of 2004, and became better balanced. The acceleration was mainly due to higher investment, but also to increased oil export volumes. Growth continued to depend heavily on the favorable external environment, in particular high oil prices, but recent increases in investment were also related to political stability, generally sound macroeconomic policies, and some structural reforms, suggesting that GDP is increasingly deriving strength from domestic factors as well.

\footnotetext{
${ }^{1}$ Under Article IV of the IMF's Articles of Agreement, the IMF holds bilateral discussions with members, usually every year. A staff team visits the country, collects economic and financial information, and discusses with officials the country's economic developments and policies. On return to headquarters, the staff prepares a report, which forms the basis for discussion by the Executive Board. At the conclusion of the discussion, the Managing Director, as Chairman of the Board, summarizes the views of Executive Directors, and this summary is transmitted to the country's authorities. This PIN summarizes the views of the Executive Board as expressed during the Executive Board discussion based on the staff report.
} 
Macroeconomic tensions have increased, however, as growth has risen and the balance of payments strengthened. While headline inflation declined to 12 percent at end-2003 and further during the first half of 2004, this was mainly due to administered price restraint; core inflation has become entrenched at 10-11 percent over the past two years. Tightening labor markets have added to inflationary pressures. With inflation still high relative to competitors and the ruble broadly stable in nominal effective terms, the pace of real ruble appreciation has increased to nearly 10 percent over the past year.

The balance of payments has strengthened further. Despite higher imports related to rapid demand growth and real appreciation, the external current account surplus has remained at 8-9 percent of GDP during the past two years, supported by high world commodity prices. Meanwhile, net private capital outflows declined substantially in 2003, reflecting higher corporate and banking sector borrowing as well as some reversal of foreign currency substitution. In the first half of 2004 , net outflows increased, with volatility reflecting periodic uncertainty linked to the Yukos affair, prospects for global interest rates, and perceived changes in the central bank's intervention and exchange rate strategy. Nonetheless, reserves accumulation continued, even as the banking system was hit by turmoil in July. Gross international reserves stood at about $\$ 88.5$ billion (over seven months of imports) at end-July. Public external debt, net of reserves, has fallen close to zero, compared with $\$ 140$ billion in 1998.

The Central Bank of Russia (CBR) has intervened heavily to slow ruble appreciation over the past 18 months. The interventions were largely unsterilized, causing a surge in money growth during 2003. Rapid broad money growth, partly reflecting conversion of cash foreign currency holdings into ruble deposits, fuelled growth in credit to the economy of around 44 percent in the year to June 2004.

The trend toward fiscal relaxation is continuing, notwithstanding some tightening in the 2004 budget. Despite higher oil prices and strong economic growth, the general government surplus increased by only $1 / 2$ percent of GDP, to 1 percent of GDP, in 2003 . This represents an underlying loosening of the fiscal stance at constant oil prices of about 1 percent of GDP. The 2004 budget envisions a moderate tightening, to be achieved through postponement of noninterest expenditure increases, but plans for the 2005 budget suggest that this will be reversed, in response to growing pressures to spend more of the oil revenue windfall on tax cuts and expenditure reforms.

Progress on structural reform has been limited. The two major reforms in 2003 relate to the financial system. The law on foreign exchange regulation introduced a far-reaching liberalization of capital flows. It allows the imposition of unremunerated deposit requirements on capital flows, and the CBR decided to introduce such requirements from August 2004. Additionally, legislation was passed to introduce mandatory insurance of household deposits.

Increased regulatory vigilance in recent months has triggered nervousness in the private banking sector. The CBR has begun to assess applications by banks for entry into the deposit 
insurance system and has strengthened enforcement of prudential standards and Anti-Money Laundering/Combating Financing of Terrorism (AML/CFT) legislation. Confidence was shaken when the CBR withdrew the license of a bank in May 2004 for AML/CFT violations, leading to a liquidity squeeze and deposit runs at some banks. Although the situation has since calmed down, reflecting prompt actions by the CBR, confidence remains fragile.

\section{Executive Board Assessment}

Directors commended the authorities' good management of the economy, and the strengthening of GDP growth and the balance of payments, driven by high oil prices, increasing oil export volumes, and strong domestic demand. They were pleased that growth was becoming broader based and better balanced, and that key social indicators were improving. However, Directors advised that, with a buoyant economy, fiscal policies should not be eased and monetary policy should focus more on controlling inflation than on resisting nominal appreciation. To maintain competitiveness and diversify the economy, they also saw a need to invigorate the pace of structural reforms.

Given the strong oil price outlook, and Russia's large international reserves and low public debt, Directors expected that growth would remain robust over the near term and that external vulnerabilities would likely remain low. They cautioned, however, that further turmoil in the banking system could damage confidence.

Directors commended the achievement of a fiscal surplus in recent years and the establishment of an oil stabilization fund. They cautioned, however, that fiscal policy should not provide additional stimulus at this point in the economic cycle, and viewed the authorities' plans to relax fiscal policy in 2005 as exacerbating pressures for real ruble appreciation, arising from the exceptionally strong balance of payments, and increasing inflationary pressures. They recommended increasing the cap on the collection of windfall oil revenues in the oil stabilization fund and considering the use of some revenues in the fund to reduce debt. Directors recognized, however that, once cyclical pressures eased, there could be a case for spending more on carefully elaborated long-term fiscal structural reforms, including on health care and pension reform, and on public infrastructure. They welcomed the authorities' plans to restructure and monetize the system of in-kind benefits, and to judiciously reduce the social tax rate, accompanied by any necessary measures to ensure achievement of the broader fiscal objectives. They concurred on the importance of further development of regional and local fiscal capacity.

Directors agreed that the central bank needed to clarify the two competing objectives of controlling inflation and managing the exchange rate. They highlighted their concern over the emphasis on stemming real ruble appreciation, because, in their view, monetary policy could not target the real exchange rate, except in the short run, and the efforts to resist appreciation had resulted in inflation becoming entrenched at a relatively high level. Most Directors felt that the cost to the economy of high inflation was not sufficiently recognized, while the cost of ruble appreciation was exaggerated. They urged the central bank to allow more nominal exchange rate flexibility, to facilitate a reduction of interest spreads and discourage speculative capital 
inflows, and to take advantage of the disinflationary impact of nominal appreciation. They also highlighted the need to strengthen the independence of the central bank.

Directors welcomed steps to liberalize the capital account. Most Directors saw unremunerated deposit requirements as, at best, a temporary measure to stem capital inflows and advised the authorities to consider the experience of other countries where such requirements have raised the cost of capital, especially for small- and medium-sized enterprises. It was felt that deposit requirements could help limit large inflows of volatile short-term capital to weak banks.

However, Directors took the view that deposit requirements should be temporary, reserved to deal with exceptionally large and volatile inflows, and should not be used to stem sustained pressure for ruble appreciation.

Directors stressed that recent turmoil in the banking sector demonstrated the urgency of strengthening prudential supervision and crisis management tools, while pressing ahead with closing unsound banks. They commended the central bank for taking prompt actions to calm the situation, including halving reserve requirements and extending interim household deposit insurance to all banks. However, they noted that extension of deposit insurance could increase moral hazard, and encouraged the central bank to be unwavering in enforcing sound prudential standards. Directors urged the authorities to give the central bank strong political support and facilitate the development of more effective instruments for further strengthening banking supervision and weeding out problem banks. In this regard, Directors welcomed the prompt action by the Duma to strengthen the bank bankruptcy law. They also encouraged further development of a private banking sector and stronger action to counter money laundering.

Directors noted that the authorities' structural reform plans were well focused and progress had been made in some areas, including pension reform. However they thought that these plans would benefit from more emphasis on specifics, as overall implementation had slowed. They encouraged the authorities not to view high oil prices and strong growth as grounds for complacency but, rather, as a unique opportunity to carry out the structural reforms needed to sustain growth over the medium term. They emphasized the importance of diversifying the economy and reducing reliance on natural resources, and in this regard, welcomed the priority given to encouraging domestic and foreign direct investment and improving the investment climate for small- and medium-sized enterprises. They also supported the focus on public administration reform, banking reform, and housing reform, and underscored the benefits of liberalizing trade and early WTO accession. They underscored the need to improve governance and the rule of law, and to resolve successfully the Yukos affair. They also emphasized the importance of reforming the energy sector, breaking up inefficient monopolies, and improving labor market flexibility.

Directors welcomed the findings of recently conducted Reports on the Observance of Standards and Codes modules on data and fiscal transparency, and the authorities' decision to publish these reports. They noted that Russia's statistical database is mostly adequate for surveillance and that dissemination practices meet most of the Special Data Dissemination Standard requirements, and welcomed the authorities' intention to subscribe to the SDDS. They also commended the progress made in strengthening fiscal transparency and financial management. 
Public Information Notices (PINs) form part of the IMF's efforts to promote transparency of the IMF's views and analysis of economic developments and policies. With the consent of the country (or countries) concerned, PINs are issued after Executive Board discussions of Article IV consultations with member countries, of its surveillance of developments at the regional level, of post-program monitoring, and of ex post assessments of member countries with longer-term program engagements. PINs are also issued after Executive Board discussions of general policy matters, unless otherwise decided by the Executive Board in a particular case. 
The Russian Federation: Selected Economic Indicators

\begin{tabular}{|c|c|c|c|c|}
\hline & 2001 & 2002 & $\begin{array}{r}2003 \\
\text { Est. }\end{array}$ & $\begin{array}{l}2004 \\
\text { Proj. }\end{array}$ \\
\hline Production and prices & \multicolumn{4}{|c|}{ (Annual percent change) } \\
\hline Real GDP & 5.1 & 4.7 & 7.3 & 7.3 \\
\hline \multicolumn{5}{|l|}{ Consumer prices } \\
\hline Annual average & 21.5 & 15.8 & 13.7 & 10.3 \\
\hline End of period & 18.6 & 15.1 & 12.0 & 10.0 \\
\hline GDP deflator & 16.5 & 15.7 & 14.2 & 12.9 \\
\hline Public sector & \multicolumn{4}{|c|}{ (In percent of GDP) } \\
\hline General government overall balance $1 /$ & 2.7 & 0.6 & 1.1 & 3.1 \\
\hline Revenue & 37.3 & 37.6 & 36.6 & 37.0 \\
\hline Expenditure & 34.6 & 37.0 & 35.5 & 33.9 \\
\hline Interest & 2.7 & 2.1 & 1.7 & 1.3 \\
\hline Non-interest & 31.9 & 34.9 & 33.8 & 32.6 \\
\hline Primary balance & 5.4 & 2.7 & 2.7 & 4.4 \\
\hline Federal government overall balance $1 /$ & 2.7 & 1.3 & 1.5 & 3.0 \\
\hline External sector & \multicolumn{4}{|c|}{ (In billions of U.S. dollars) } \\
\hline Total exports & 102 & 107 & 136 & 174 \\
\hline Total imports & 54 & 61 & 75 & 96 \\
\hline External current account (deficit -) & 33 & 31 & 36 & 47 \\
\hline Stock of public external debt & 112 & 103 & 94 & 88 \\
\hline $\begin{array}{l}\text { Gross reserves coverage (in months of } \\
\text { imports of GNFS) }\end{array}$ & 5.0 & 5.6 & 7.1 & 7.6 \\
\hline \multicolumn{5}{|l|}{ Memorandum items: } \\
\hline Nominal GDP (in billions of rubles) & 8,944 & 10,834 & 13,285 & 16,090 \\
\hline $\begin{array}{l}\text { Exchange rate (rubles per U.S. dollar, } \\
\text { period average) }\end{array}$ & 29.2 & 31.3 & 30.7 & $\cdots$ \\
\hline $\begin{array}{l}\text { Russian oil price (U.S. dollars per } \\
\text { barrel, c.i.f.) }\end{array}$ & 22.9 & 23.6 & 27.3 & 30.1 \\
\hline
\end{tabular}

Sources: Russian authorities; and IMF staff estimates and projections.

1/ Commitment basis. 